\title{
The Upper Cretaceous Ammonite Rhaeboceras Meek in the Western Interior of the United States
}

U.S. GEOLOGICALSURVEYPROFESSIONAL PAPER 1477

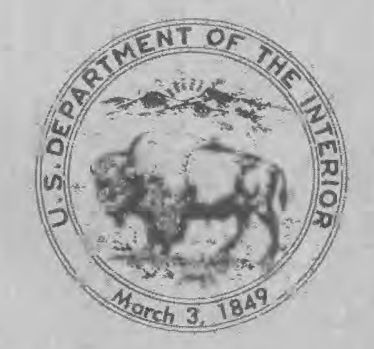




\section{The Upper Cretaceous Ammonite Rhaeboceras Meek in the Western Interior of the United States}

By WILLIAM A. GOBBAN

U.S. GEOLOGICAL SURVEY PROFESSIONAL PAPER 1477

Descriptions and illustrations of

an important guide fossil to

rocks of early Maastrichtian age

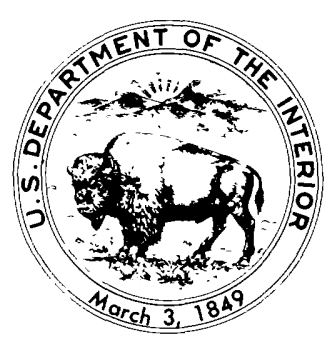




\section{DEPARTMENT OF THE INTERIOR}

DONALD PAUL HODEL, Secretary

\section{U.S. GEOLOGICAL SURVEY}

Dallas L. Peck, Director

Library of Congress Cataloging in Publication Data

Cobban, William A., 1916-

The Upper Cretaceous ammonite Rhaeboceras Meek in the Western Interior of the United States.

(U.S. Geological Survey professional paper ; 1477)

Bibliography: p. 13

1. Rhaeboceras. 2. Paleontology-Cretaceous. 3. Paleontology-West (U.S.) I. Title. II. Series: Geological Survey professional paper ; 1477.

For sale by the

Books and Open-File Reports Section

U.S. Geological Survey

Federal Center

Box 25425

Denver, CO 80225 


\section{CONTENTS}

\begin{tabular}{|c|c|c|c|}
\hline \multicolumn{3}{|c|}{ Page } & \multirow[t]{2}{*}{ Page } \\
\hline Abstract & 1 & Systematic descriptions-Continued & \\
\hline Introduction & 1 & Rhaeboceras subglobosum (Whiteaves) & 10 \\
\hline Acknowledgments & 2 & Rhaeboceras subglobosum (Whiteaves), noded variant & 11 \\
\hline Stratigraphic position of Rhaeboceras & 2 & Rhaeboceras coloradoense Cobban, n. sp. . . . . . . & 11 \\
\hline Geographic distribution & 2 & Rhaeboceras coloradoense Cobban, $\mathrm{n}$. sp., noded & \\
\hline Classification & 2 & variant $\ldots \ldots$ & 12 \\
\hline Systematic descriptions & 5 & Rhaeboceras burkholderi Cobban, $\mathrm{n}$. sp. & 12 \\
\hline Rhaeboceras halli (Meek and Hayden) & 6 & Rhaeboceras cf. $R$. burkholderi Cobban, n. sp. . & 13 \\
\hline Rhaeboceras halli (Meek and Hayden), noded variant & 9 & References cited & 13 \\
\hline Rhaeboceras mullananum (Meek and Hayden) & 9 & Index & 15 \\
\hline
\end{tabular}

\section{ILLUSTRATIONS}

[Plates follow index]

Plates 1-14. Rhaeboceras

FIGURE 1. Map showing localities of Rhaeboceras

2. Scatter diagram of ventral ribs of Rhaeboceras halli (Meek and Hayden). 7

3. Histogram of diameters at base of body chambers of Rhaeboceras halli (Meek

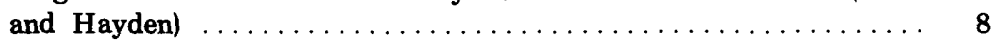

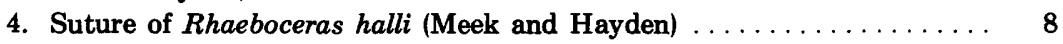

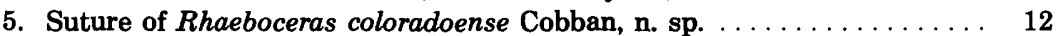

6. Suture of Rhaeboceras burkholderi Cobban, n. sp. ............ 13

\section{TABLE}

TABLE 1. Localities where Rhaeboceras was collected $\ldots \ldots \ldots \ldots \ldots \ldots \ldots \ldots$ 



\title{
THE UPPER CRETACEOUS AMMONITE RHAEBOCERAS MEEK IN THE WESTERN INTERIOR OF THE UNITED STATES
}

\author{
By William A. CobBan
}

\begin{abstract}
The genus Rhaeboceras Meek, 1876, of early Maastrichtian age, is characterized by its body chamber which is deflected a little from the regular curve of the phragmocone and by its conspicuous umbilical bullae. Some species, such as the type, $R$. halli (Meek and Hayden), have dense ribbing on the outer whorl of the phragmocone. The suture, which is typical of the scaphites, has five lobes in the external part that decrease progressively in height away from the venter, and the first lateral saddle is asymmetrically bifid with the widest part nearest the venter. The genus is best assigned to the family Scaphitidae Meek.

Rhaeboceras is known in North America only from western Kansas and northern Colorado northward into Alberta and Saskatchewan. Six species have been described, and two new ones, $R$. coloradoense and $R$. burkholderi, are herein described. One species, $R$. mullananum (Meek and Hayden), which is known only from the holotype, may be older (Santonian?) than the other species (early Maastrichtian). Ancestral forms of Rhaeboceras are unknown. The genus gave rise to Ponteixites Warren, 1934, later in the Maastrichtian.
\end{abstract}

\section{INTRODUCTION}

Meek (1876, p. 458-462, pl. 24, figs. 3a-c, text fig. 64) proposed the genus Rhaeboceras for an ammonite that seemed to combine features of both Phylloceras Suess $(1866$, p. 76$)$ and Scaphites Parkinson (1811, p. 145, pl. 10, fig. 10). Phylloceras is an involute form that has numerous fine radial ribs or lirae and a complex suture characterized by rounded leaf-shaped folioles in the saddles. Scaphites is a more or less involute form that becomes partly uncoiled in the adult stage. The type species of Rhaeboceras is Ammonites halli Meek and Hayden (1856, p. 70). Meek (1876, p. 458-462) gave a revised description of the two only known specimens, both crushed, and noted that "Should complete undistorted specimens show, as I think very probably will be the case, that it differs generically or subgenerically from Phylloceras proper, I would propose for the group into which it would in that case naturally fall, the name Rhaeboceras."

Rhaeboceras is common in parts of the Bearpaw Shale (Upper Cretaceous) of central Montana and southern Alberta and Saskatchewan and in the Larimer and Richard Sandstone Members of the Pierre Shale (Upper Cretaceous) of north-central Colorado. Aside from these occurrences, specimens referable to Rhaeboceras are exceedingly rare; a few specimens have been collected from the base of the Lewis Shale (Upper Cretaceous) in central Wyoming, a single specimen was found in the Pierre Shale near Red Bird in eastern Wyoming, and one specimen each was found in the Pierre Shale in North Park, Colorado, southeastern Wyoming, northwestern Nebraska, and western Kansas. Outside North America, Rhaeboceras may be represented by the ammonite described as Acanthoscaphites innodosus Naidin $(1974$, p. 178, pl. 62) from the Donetz Basin, U.S.S.R. An ammonite listed as $\mathrm{Am}$ monites halli Meek and Hayden? has been recorded from Brazil (Magalhães and Mezzalira, 1953, p. 276).

Six species of Rhaeboceras have been described from the United States and Canada. These species, with their original generic assignments, are Ammonites opalus Owen (1852, p. 579), A. halli Meek and Hayden (1856, p. 70), $A$. mullananus Meek and Hayden $(1862$, p. 23), Scaphites subglobosus Whiteaves (1885, p. 52), Acanthoscaphites albertensis Warren (1930, p. 23), and Rhaeboceras whiteavesi Landes (1940, p. 174).

Records of Rhaeboceras from the United States are few and scattered in the literature. Rhaeboceras halli was first described by Meek and Hayden in 1856 (p. 70), listed by them in 1860 (p. 420) and by Meek in 1864 (p. 24), and redescribed by Meek in 1876 (p. 458). Nothing new was recorded concerning this species in the United States until Scott and Cobban (1959, p. 128) noted its occurrence in the Larimer Sandstone Member of the Pierre Shale in northern Colorado, and Cobban (1962, p. 127) recorded it with Baculites jenseni Cobban in the Bearpaw Shale in central Montana.

Rhaeboceras mullananum was described by Meek and Hayden in 1862 (p. 23), listed by Meek in 1864 (p. 24), and redescribed by Meek in 1876 (p. 607). Stanton (1893, p. 187) repeated Meek's description and illustrations, but Stanton assigned the species to Scaphites. This assignment was accepted by Diener (1925, p. 201) in his classification of Upper Cretaceous ammonites as well as by Reeside $(1927$, p. 31$)$ in his general account of the scaphites.

Rhaeboceras albertense, which was noted by Jensen and Varnes (1964, p. F10) in the upper part of the 
Bearpaw Shale in northeastern Montana, seems to be the only published record of this species in the United States.

\section{ACKNOWLEDGMENTS}

Mr. Larry C. Eichhorn, Lewistown, Mont., kindly made available his large and impressive collections of Rhaeboceras from the Bearpaw Shale. Several of his specimens are illustrated in this report. Other specimens of Rhaeboceras were donated by Richard L. Sutton, Jr., M.D., Prairie Village, Kans., Dr. Gale A. Bishop, Georgia Southern College, Statesboro, Ga., Mr. Karl F. Hirsch, Denver, Colo., Dr. E.A. Hamilton, Marietta, Ohio, Mr. Robert H. Feldman, Billings, Mont., and Mr. Howard Ehrle, Miles City, Mont.

The specimens illustrated in this report are stored in the National Museum of Natural History in Washington, D.C. Plaster casts of many of the specimens are in the U.S. Geological Survey Mesozoic invertebrate fossil collections at the Federal Center, Denver, Colo. All photographs were made by Robert E. Burkholder of the U.S. Geological Survey.

\section{STRATIGRAPHIC POSITION OF RHAEBOCERAS}

The general stratigraphic position of Rhaeboceras was shown by Gill and Cobban (1966, p. A35) to include the zones of Baculites reesidei Elias and $B$. jenseni Cobban. Jeletzky (1968, p. 48) later defined a "Scaphites nodosus and Rhaeboceras spp. zone" in the Bearpaw Shale in the Western Interior of Canada. In the United States Hoploscaphites nodosus (Owen) is most common and best developed in the zones of Baculites reesidei and $B$. jenseni.

The large collections of Rhaeboceras now at hand seem to indicate only two zones. The lower zone, which coincides with the zone of Baculites reesidei, is characterized by very stout forms of Rhaeboceras, and it is probably the level from which came the types of $R$. subglobosum and $R$. whiteavesi. The more slender forms of Rhaeboceras, $R$. halli and $R$. albertense, characterize the upper zone which coincides with the zone of Baculites jenseni. There is the possibility that $R$. mullananum marks an older zone, but this cannot be verified at present.

\section{GEOGRAPHIC DISTRIBUTION}

The collections of Rhaeboceras studied came from many localities in Montana, Wyoming, and Colorado, but most are from the Bearpaw Shale of central and north-central Montana. The localities of Rhaeboceras are indicated in figure 1 , and the individual localities are described in table 1.

\section{CLASSIFICATION}

The classification of Rhaeboceras has been a problem. Meek (1876, p. 460) assigned it to Phylloceras because "In general form (at least in medium-sized specimens), as well as in the roundness of its periphery and the general characters of its septa, it agrees pretty well with that genus." He queried this assignment, however, because the suture differed somewhat from Phylloceras, and the body chamber deflected from the regular curve of the phragmocone. Diener (1925, p. 121) thought Meek and Hayden's Ammonites halli more closely resembled Pusozia (Bayle, 1878, pls. 45, 46), and he assigned it with a query to that genus.

The ammonite described by Meek and Hayden (1862, p. 23) as Ammonites mullananus was considered a scaphite and assigned to Scaphites by Stanton (1893, p. 187) as well as by Diener (1925, p. 201) and Reeside (1927, p. 31).

Rhaeboceras albertense was originally assigned to Acanthoscaphites Nowak (1912, p. 565) by Warren (1930, p. 23) owing to its general scaphitoid appearance. Warren also suggested that Meek and Hayden's Ammonites halli might also be referred to Acanthoscaphites. Rhaeboceras subglobosum was also considered a scaphite by Whiteaves $(1885$, p. 52$)$, who assigned his new species to Scaphites and compared it to $S$. nodosus Owen (1852, p. 581). On the other hand, Landes (1940, p. 174) considered Rhaeboceras distinct from the scaphites and assigned it to the family Cosmoceratidae and subfamily Acanthoceratinae. In the most recent treatment of the genus, Wright (1957, p. L229) placed it in the family Scaphitidae and subfamily Scaphitinae.

Some ammonites from the southern hemisphere, such as Grossouvrites Kilian and Reboul $(1909$, p. 26, 38) resemble fine-ribbed $R$ haeboceras in their dense ribbing and conspicuous umbilical tubercles. The large specimen of G. gemmatus (Huppe), figured by Spath (1953, p. 29, pl. 5, figs. 1a, b) from Graham Land, closely resembles some specimens of Rhaeboceras (such as pl. 10), but its suture is quite different. Likewise, the specimen of $G$. gemmatus illustrated by Steinmann $(1895$, p. 68, pl. 6 , figs. 1a, b) resembles $R$. halli in its fine ribbing and umbilical tuberculation, but the umbilicus is a little wider, and the tubercles are present well within the inner whorls.

The scaphitoid body chamber and the suture pattern certainly relate Rhaeboceras to the scaphites. As in the scaphites (Cobban, 1951, p. 4), the external suture has five lobes progressively decreasing in height away from 
CLASSIFICATION

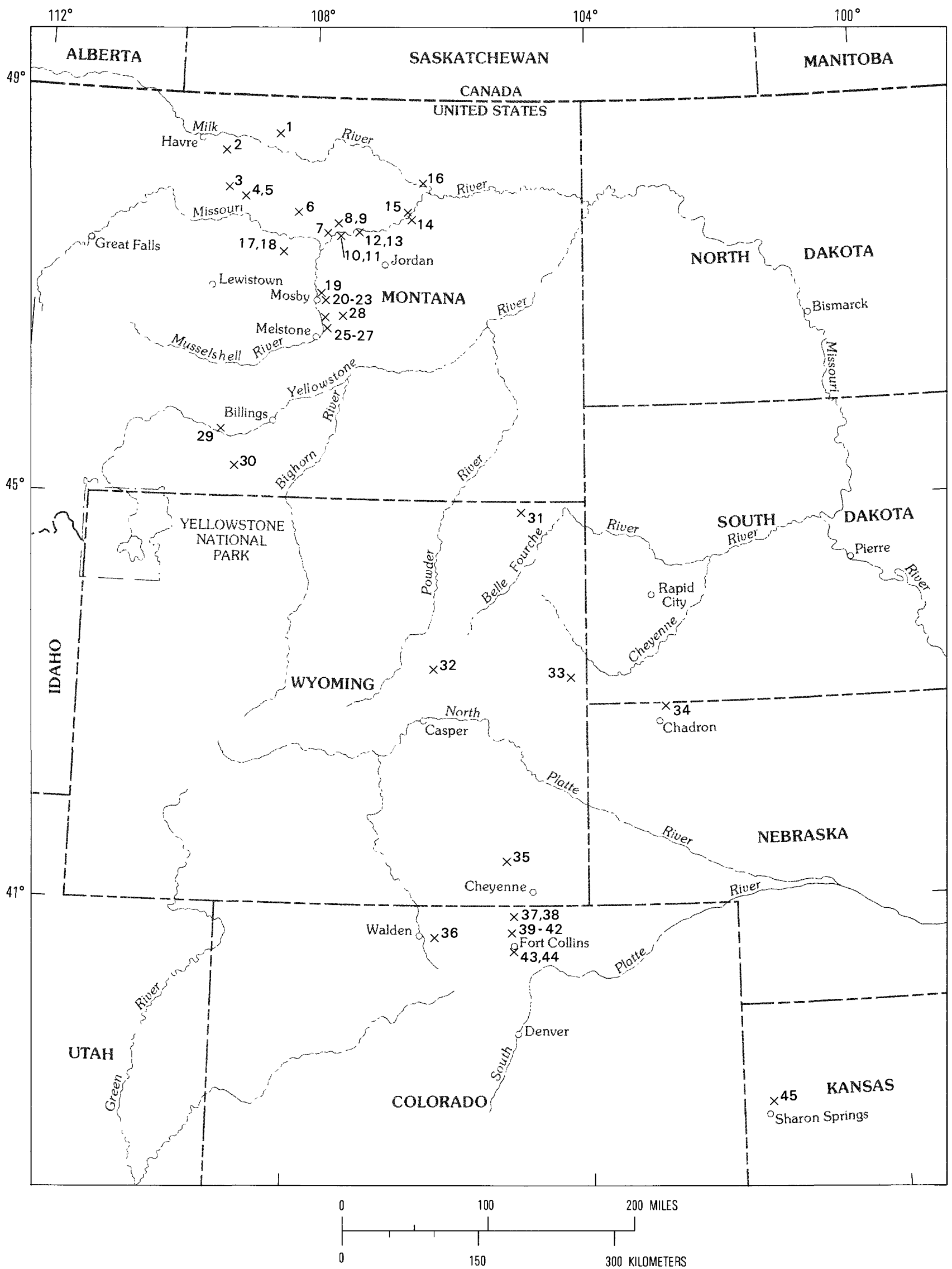

FIgURE 1.-Index map of part of the Western Interior of the United States showing localities of Rhaeboceras referred to in the text and in table 1. 
TABLE 1.-Localities where Rhaeboceras was collected

\begin{tabular}{|c|c|c|}
\hline $\begin{array}{l}\text { Locality } \\
\text { (fig.1) }\end{array}$ & $\begin{array}{l}\text { USGS } \\
\text { Mesozoic } \\
\text { locality }\end{array}$ & $\begin{array}{l}\text { Collector, year of collection, description } \\
\text { of locality, and stratigraphic assignment }\end{array}$ \\
\hline 1 & 5517 & $\begin{array}{l}\text { V.H. Barnett, } 1908 \text {. About } 19 \mathrm{~km} \text { north of Savoy, in } \\
\text { the NW } 1 / 4 \text { NE}^{1 / 4} \text { sec. } 7 \text {, T. } 33 \text { N., R. } 25 \text { E., Blaine } \\
\text { County, Mont. Bearpaw Shale. }\end{array}$ \\
\hline 2 & D1338 & $\begin{array}{l}\text { R.G. Schmidt, 1957. About } 15 \mathrm{~m} \text { northeast of large } \\
\text { reservoir dam, in sec. } 13 \text {, T. } 31 \text { N., R. } 18 \mathrm{E} \text {., Blaine } \\
\text { County, Mont. Bearpaw Shale, possibly } 45-60 \mathrm{~m} \\
\text { below top. }\end{array}$ \\
\hline 3 & 2836 & $\begin{array}{l}\text { J.B. Hatcher and T.W. Stanton, 1903. Cow Creek near } \\
\text { middle of T. } 27 \text { N., R. } 19 \text { E., Blaine County, Mont. } \\
\text { Bearpaw Shale. }\end{array}$ \\
\hline
\end{tabular}

D2283 B.C. Hearn, Jr., 1959. Southeast side of Bearpaw Mountains, in the $\mathrm{N}^{1} 1 / 2 \mathrm{NW}^{1} / 4 \mathrm{SE}^{1} / 4$ sec. 7 , T. $26 \mathrm{~N}$., R. 21 E., Blaine County, Mont. Bearpaw Shale, possibly $105-120 \mathrm{~m}$ above base.

5

D2296 B.C. Hearn, Jr., 1959. Near D2283 in the SE $1 / 4 N^{1} 1 / 4 N^{1 / 4}$ sec. 7, T. 26 N., R. 21 E., Blaine County, Mont. Bearpaw Shale.

6

22095 E.A. Hamilton, 1949. Sec. 9 or 16, T. 24 N., R. 27 E., Phillips County, Mont. Bearpaw Shale.

7 D9514 C.A. Wolfbauer, 1975. North of Fort Peck Reservoir, in the NW1/4 SE $1 / 4 \mathrm{NW}^{1 / 4}$ sec. 6, T. 21 N., R. 31 E., Phillips County, Mont. Bearpaw Shale, from a gray limestone concretion about $95 \mathrm{~m}$ below top.

D10233 L.C. Eichhorn, 1973. North of Fort Peck Reservoir, in secs. 1-4, T. 22 N., R. 31 E., and secs. 33-35, T. 23 N., R. 31 E., Phillips County, Mont. Bearpaw Shale.

9

D12735 Howard Ehrle, 1986. Telegraph Creek area of southeastern Phillips County, Mont. Bearpaw Shale.

D10223 R.I. Sutton, Jr., 1970. South side of Fort Peck Reservoir, in the center of sec. 11, T. 21 N., R. 31 E., Garfield County, Mont. Bearpaw Shale, from dusky-red-weathering concretions.

D10222 R.L. Sutton, Jr., 1970. South side of Fort Peck Reservoir at mouth of Devils Creek, in the $S 1 / 2$ sec. 32, T. 22 N., R. 32 E., Garfield County, Mont. Bearpaw Shale, from dusky-red-weathering concretions.

D10221 R.L. Sutton, Jr., 1970. South side of Fort Peck Reservoir, in the NW1/4 sec. 14, T. 22 N., R. 34 E., Garfield County, Mont. Bearpaw Shale.

D10224 R.L. Sutton, Jr., 1970. North side of Fort Peck Reservoir at mouth of Timber Creek, in the NE1/4 sec. 4, T. 22 N., R. 34 E., Valley County, Mont. Bearpaw Shale, from dusky-red-weathering concretions.

D10225 R.L. Sutton, Jr., 1970. South side of Fort Peck Reservoir near mouth of Gilbert Creek, in the N1/2 T. 23 N., R. 40 E., Garfield County, Mont. Bearpaw Shale.
TABLE 1.-Localities where Rhaeboceras was collected-Continued

\begin{tabular}{ccc}
$\begin{array}{c}\text { Locality } \\
\text { (fig.1) }\end{array}$ & $\begin{array}{c}\text { USGS } \\
\text { Mesozoic } \\
\text { locality }\end{array}$ & $\begin{array}{c}\text { Collector, year of collection, description } \\
\text { of locality, and stratigraphic assignment }\end{array}$ \\
\hline
\end{tabular}

15 D10226 G.A. Bishop, 1973. North side of Fort Peck Reservoir, in the SW1/4 sec. 7, T. 24 N., R. 40 E., Valley County, Mont. Bearpaw Shale, 45-60 m below top.

23390 F.S. Jensen, 1950. Three kilometers northwest of Nashua, in the $\mathrm{NE}^{1 / 4}$ sec. 26, T. 28 N., R. 41 E., Valley County, Mont. Bearpaw Shale, from a dusky-red-weathering concretion 80 or $90 \mathrm{~m}$ below top.

D10234 L.C. Eichhorn, 1970. Along drainage of Crooked Creek in northeastern Fergus County, Mont. Bearpaw Shale.

23338 O.O. Mueller, 1954. Crooked Creek in sec. 33, T. 20 N., R. 26 E., Fergus County, Mont. Bearpaw Shale.

D5675 J.R. Gill, 1966. About $6.4 \mathrm{~km}$ north of Mosby, in the NW $1 / 4$ sec. 23 , T. 15 N., R. 30 E., Garfield County, Mont. Bearpaw Shale, from a gray limestone concretion in a bentonitic unit about $213 \mathrm{~m}$ above base of formation.

D5663 R.E. Burkholder, 1966. About $11 \mathrm{~km}$ east of Mosby, in the center of the NW1/4 sec. 10, T. 14 N., R. 31 E., Garfield County, Mont. Bearpaw Shale, from brown-weathering, ferruginous limestone concretions just below a bentonitic unit and about $204 \mathrm{~m}$ above base of formation.

D5664 J.R. Gill, R.E. Burkholder, and W.A. Cobban, 1966. Same locality as D5663. Bearpaw Shale, from bentonitic unit about 205-212 $\mathrm{m}$ above base of formation.

D5668 J.R. Gill and R.E. Burkholder, 1966. About 7 km northeast of Mosby, in the SW1/4 SW $1 / 4$ sec. 33, T. 15 N., R. 31 E., Garfield County, Mont. Bearpaw Shale, from limestone concretions in bentonitic unit about $213 \mathrm{~m}$ above base of formation.

21580 W.A. Cobban and C.T. Moore, 1949. Eight kilometers east-northeast of Mosby, in the $W^{1 / 2}$ sec. 3, T. 14 N., R. 31 E., Garfield County, Mont. Bearpaw Shale, from bentonitic unit about $205-212 \mathrm{~m}$ above base.

D783 H.R. Smith, P.W. Richards, and W.A. Cobban, 1955. About $23 \mathrm{~km}$ north-northeast of Melstone, in the NW $1 / 4$ sec. 24, T. 12 N., R. 31 E., Rosebud County, Mont. Bearpaw Shale, about 270-275 $\mathrm{m}$ above base.

D781 H.R. Smith, 1955. Nineteen kilometers northeast of Melstone, in the $\mathrm{SE}^{1 / 4} \mathrm{SE}^{1 / 4} \mathrm{SE}^{1 / 4}$ sec. 6, T. 11 N., R. 32 E., Rosebud County, Mont. Bearpaw Shale, from gray-weathering limestone concretions about $280 \mathrm{~m}$ above base.

21660 C.T. Moore and W.A. Cobban, 1949. Sixteen kilometers northeast of Melstone, in the NE1/4 sec. 24, T. 11 N., R. 31 E., Rosebud County, Mont. Bearpaw Shale, from brown-weathering limestone concretions. 
TABLE 1.-Localities where Rhaeboceras was collected-Continued

\begin{tabular}{ccc}
\hline $\begin{array}{c}\text { Locality } \\
\text { (fig.1) }\end{array}$ & $\begin{array}{c}\text { USGS } \\
\text { Mesozoic } \\
\text { locality }\end{array}$ & $\begin{array}{c}\text { Collector, year of collection, description } \\
\text { of locality, and stratigraphic assignment }\end{array}$ \\
\hline
\end{tabular}

D12734 R.H. Feldman, 1986. North-northeast of Melstone in the SE $1 / 4 \mathrm{SW}^{1 / 4} \mathrm{SW}^{1 / 4}$ sec. 11 , T. 11 N., R. $31 \mathrm{E}$., Rosebud County, Mont. Bearpaw Shale.

22094 E.A. Hamilton, 1949. T. 12 N., R. 33 E., Rosebud County, Mont. Bearpaw Shale.

12853 R.S. Knappen, 1924. About $5 \mathrm{~km}$ northeast of Columbus, in the SW1/4 sec. 13, T. 2 S., R. 20 E., Stillwater County, Mont. Bearpaw Shale.

5006 T.W. Stanton, 1907. About $6.4 \mathrm{~km}$ west of Bridger, Carbon County, Mont. Bearpaw Shale.

D440 C.S. Robinson, W.J. Mapel, and W.A. Cobban, 1955. NE $1 / 4 N^{1 / 4}$ sec. 24, T. 56 N., R. 69 W., Cainpbell County, Wya Pierre Shale, about $15 \mathrm{~m}$ above top of Monument Hill Bentonitic Member.

D3228 J.R. Gill and W.A. Cobban, 1960. Northeast flank of Teapot dome, in the SW1/4 SW1/4 sec. 24 , T. 39 N., R. 78 W., Natrona County, Wyo. Lewis Shale, from brown-weathering limestone concretions about $17 \mathrm{~m}$ above base.

D10236 K.F. Hirsch, 1972. About $3.2 \mathrm{~km}$ northeast of Red Bird, in the SE $1 / 4$ sec. 14, T. 38 N., R. 62 W., Niobrara County, Wyo. Pierre Shale, from a ferruginous concretion probably just beneath Kara Bentonitic Member.

D4943 W.A. Cobban, 1965. About $18 \mathrm{~km}$ north-northeast of Chadron in the SE1/4 sec. 25, T. 35 N., R. 48 W., Dawes County, Nebr. Pierre Shale.

D1382 G.R. Scott and W.A. Cobban, 1957. About 0.8 km east of Horse Creek, in the NE $1 / 4 \mathrm{SE}^{1 / 4} \mathrm{sec} .25$, T. 17 N., R. 70 W., Laramie County, Wyo. Pierre Shale, from gray- and brown-weathering sandy limestone concretions $15 \mathrm{~m}$ above Larimer Sandstone Member.

D9637 D.J. Hill Madden and M.A. Moorman, 1975. Thirteen kilometers west of Walden, in the $\mathrm{SE}^{1 / 4} \mathrm{SW}^{1 / 4}$ sec. 26, T. 9 N., R. 78 W., Jackson County, Colo. Pierre Shale, from a sandy limestone concretion.

D371 G.R. Scott, 1955 . About $1.3 \mathrm{~km}$ southwest of Round Butte, in the NW1/4SW1/4 sec. 19 , T. 11 N., R. 68 W., Larimer County, Colo. Pierre Shale, from a brown-weathering sandstone concretion in the Larimer Sandstone Member.

D374 G.R. Scott and W.A. Cobban, 1955. About $0.8 \mathrm{~km}$ south of Round Butte, in the SE1/4NW1/4 sec. 19, T. 11 N., R. 68 W., Larimer County, Colo. Pierre Shale, from brown-weathering sandstone concretions in upper $6 \mathrm{~m}$ of Richard Sandstone Member.

16093 R.G. Coffin, 1931. South bank of Reservoir No. 3, in the $\mathrm{N}^{1 / 2} \mathrm{SE}^{1 / 4}$ sec. 19 , T. 9 N., R. 68 W., Larimer County, Colo Pierre Shale, from gray silty limestone concretions in Richard Sandstone Member.
TABLE 1.-Localities where Rhaeboceras was collected-Continued

\begin{tabular}{ccc}
$\begin{array}{c}\text { Locality } \\
\text { (fig.1) }\end{array}$ & $\begin{array}{c}\text { USGS } \\
\text { Mesozoic } \\
\text { locality }\end{array}$ & $\begin{array}{c}\text { Collector, year of collection, description } \\
\text { of locality, and stratigraphic assignment }\end{array}$ \\
\hline 40 & 22921 & $\begin{array}{c}\text { J.B. Reeside, Jr., H.R. Christner, and W.A. Cobban, } \\
\text { 1950; Cobban and G.R. Scott, 1955-1972. Saine } \\
\text { locality and stratigraphic position as 16093. }\end{array}$
\end{tabular}

41

D2715 G.R. Scott, 1960. Along irrigation ditch $0.2 \mathrm{~km}$ northwest of Reservoir No. 8, in the SW1/4 SE1/4 sec. 25, T. 9 N., R. 69 W., Larimer County, Colo. Pierre Shale, Richard Sandstone Member.

D1465 G.R. Scott and W.A. Cobban, 1957. About $0.8 \mathrm{~km}$ northeast of Waverly, in the SW1/4SE1/4 SW1/4 sec. 13, T. 9 N., R. 69 W., Larimer County, Colo. Pierre Shale, from gray limestone concretions in Larimer Sandstone Member.

D300 G.R. Scott and W.A. Cobban, 1955. West side of ridge just east of U.S. Highway 287, in the W1/2SW1/4SW1/4 sec. 1, T. 6 N., R. 69 W., Larimer County, Cola. Pierre Shale, from brown-weathering sandstone concretions in middle of Larimer Sandstone Member.

D301 G.R. Scott and W.A. Cobban, 1955. Saine locality as D300. Pierre Shale, from uppermost ledge of Larimer Sandstone Member.

D618 W.A. Cobban, 1955. About $18.5 \mathrm{~km}$ north-northeast of Sharon Springs in the NE1/4 sec. 31 , T. $11 \mathrm{~S}$., R. 39 W., Wallace County, Kans. Pierre Shale, from upper part of Lake Creek Member.

the venter, and the first lateral saddle is asymmetrically bifid with the widest part on the ventral side.

The large nodeless and densely ribbed phragmocone is a feature not seen on other forms of large scaphites. Ventrolateral tubercles, which are present on most scaphites of Campanian and Maastrichtian age, are absent on most specimens of Rhaeboceras.

\section{SYSTEMATIC DESCRIPTIONS}

The specimens that are described or mentioned in this report have the following repository abbreviations: USNM (National Museum of Natural History, Washington, D.C.; formerly U.S. National Museum); GSC (Geological Survey of Canada, Ottawa, Ontario); UA (Department of Geology, University of Alberta, Edmonton); and FM (Field Museum of Natural History, Chicago, Ill.).

In the drawings of sutures, the heavy, solid straight line marks the middle of the venter as well as the middle of the external lobe $(\mathrm{E})$; the lighter, solid straight line marks the middle of the dorsum as well as the middle of the internal lobe (I); and the dashed line marks the 
umbilical seam. Only the major lateral lobe and saddle are identified; $\mathrm{L}$ stands for the lateral lobe, and $\mathrm{E} / \mathrm{L}$ stands for the saddle that separates this lobe from the external one (E).

Family SCAPHITIDAE Meek, 1876, p. 413 Subfamily SCAPHITINAE Meek, 1876, p. 413 Genus RHAEBOCERAS Meek, 1876, p. 462 Rhaeboceras halli (Meek and Hayden)

Plates 1-5; plate 6, figures 1-15; plate 7, figure 2; plate 8, figures 1, 2 ; plate 11 , figures 5,6 ; plate 12 , figures $1-3$; plate 13

1852. Ammonites opalus Owen, p. 579, pl. 8, fig. 6 (nomen oblitum). 1856. Ammonites halli Meek and Hayden, p. 700.

1859. Ammonites halli Meek and Hayden. Hayden, p. 684.

1860. Ammonites halli Meek and Hayden. Meek and Hayden, p. 420.

1876. Phylloceras? halli (Meek and Hayden). Meek, p. 458, pl. 24, figs. 3a-c; Rhaeboceras halli on p. 462.

1925. Puzosia? halli (Meek and Hayden). Diener, p. 121.

1957. Rhaeboceras halli (Meek and Hayden). Wright, p. L229, fig. 255 (5a, b).

1983. Rhaeboceras halli (Meek and Hayden). Riccardi, p. 33, pl. 12, figs. 1-6; pl. 13, figs. 1-4, 8; text figs. 32-35.

Types.-Holotype USNM 384 by original designation is the original of Meek and Hayden (1856, p. 70) first illustrated by Meek (1876, pl. 24, figs. 3a-c) from rocks now assigned to the Bearpaw Shale in northeastern Montana. Unfigured paratype USNM 389 from the same locality. Hypotypes USNM 413012-413038, 413100-413102.

Diagnosis.-A slender to moderately slender species that has extremely dense to moderately dense ribbing.

Description.-Meek had only two specimens of which the smaller and better preserved one was figured. This specimen, the holotype, is a small adult that consists of a slender uncrushed phragmocone and most of the body chamber which, however, is laterally crushed and lacks the oral end (pl. 1, figs. 11, 12). Meek gave its dimensions as " 4.70 inches in its greatest diameter, and about 1.50 inches in convexity." He noted that the "surface ornamented with numerous small, bifurcating, slightly flexuous costae, that are larger near the umbilical side, and on the last turn of medium and large sized specimens become proportionally somewhat more prominent, more curved, and suddenly bifurcate near the umbilicus, and again divide and subdivide into numerous smaller ones, so that their number, including others intercalated between, amounts to from five to seven times as many where they pass straightly over the periphery, as near the umbilical side." Meek also noted that the umbilicus was very narrow in the phragmocone but proportionally wider in the body chamber. He was impressed by the manner in which the body chamber deflected from the regular curve of the inner whorls. The unfigured paratype, USNM 389 , a large badly crushed adult, seemed to have two deflections from the regular curve of the inner whorls. This angularity was undoubtedly the source of the name Rhaeboceras (Greek, rhaibos, bent).

The holotype has 12 primary ribs and 75 secondary ribs per half whorl at a diameter of $80 \mathrm{~mm}$. The primaries curve forward and, on the body chamber and adjoining part of the phragmocone, rise into conspicuous bullae along the umbilical shoulder. On the outer part of the flank, the primaries divide into secondaries which are of equal size on crossing the venter. All ribs are slightly flexuous and rectiradiate.

The uncrushed phragmocone of the holotype has flattened flanks, a narrowly rounded venter, and a whorl section that is considerably higher than wide. The well-preserved suture was illustrated by Meek (1876, pl. 27, fig. 3c; text fig. 64).

Meek's unpublished paratype (USNM 389) came from a dusky-red-weathering sideritic concretion. The specimen is so badly crushed as to be of little value other than to indicate a large adult size (248 $\mathrm{mm}$ in diameter) and to show the deflection of the body chamber from the regular curve of the phragmocone.

Two large collections of Rhaeboceras that seem referable to $R$. halli were available for study. Both are from the zone of Baculites jenseni Cobban in the upper part of the Bearpaw Shale of east-central Montana. The larger collection, made available by $\mathrm{Mr}$. Larry $\mathrm{C}$. Eichhorn of Lewistown, Mont., consists of 124 specimens suitable for one or more measurements, such as umbilical ratio, diameter at base of body chamber, and rib count. Mr. Eichhorn kindly donated most of these specimens which came from map locality 17 (D10234) on figure 1. The other collection, from USGS Mesozoic locality D783 (fig. 1, loc. 24), consists of 116 specimens suitable for one or more measurements.

Most specimens in the two large collections are not as slender or as finely ribbed as the holotype of $R$. halli. The ratio of breadth to diameter of the shell and the number of ribs crossing the venter can best be shown by means of scatter diagrams (fig. 2). Measurements of the holotype of $R$. halli are also included; it is readily apparent that the type lies at the extreme slender end of the variation in breadth and near the fine end of the variation in rib density. The holotype, accordingly, is not typical of fairly large populations that I believe represent this species.

The extreme variation in rib density is unusual (pl. 2). At small diameters, the spread in rib density is low, but as the shells enlarge the rib density increases at varying rates. On some individuals, the increase in rib density is almost abrupt (pl. 3, fig. 2).

The primary ribs, which are numerous and well defined even on the small inner whorls (pl. 1, figs. 4-6), 


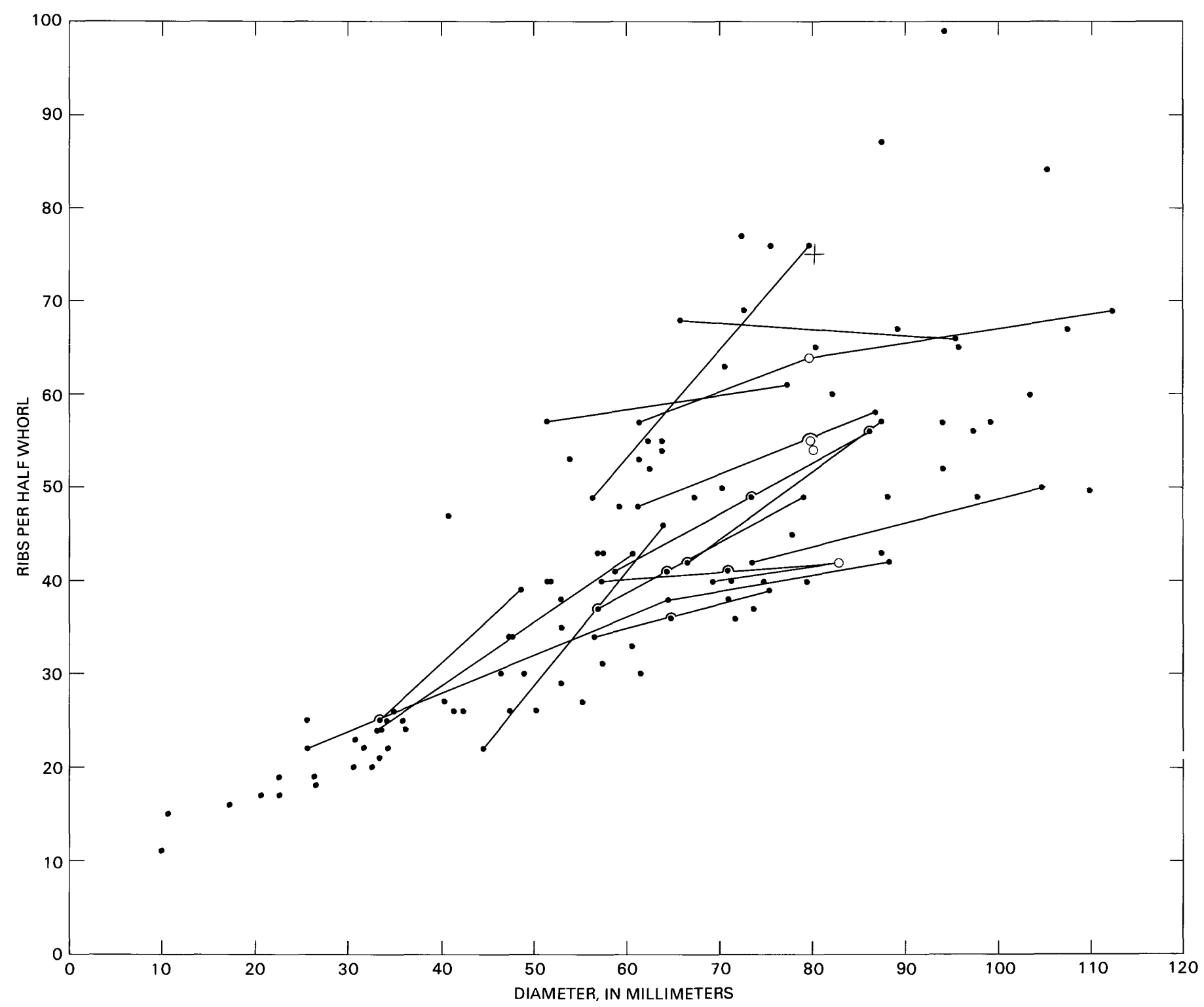

FIGURE 2.-Scatter diagram showing number of ventral ribs per half whorl of Rhaeboceras halli (Meek and Hayden) from the Bearpaw Shale at USGS Mesozoic locality D783 (fig. 1, loc. 24). Dots connected by lines represent measurements on single specimens; open circles indicate two specimens that have the same measurements. The cross indicates measurements on the holotype.

become bullate on the umbilical shoulder of the body chamber and adjoining part of the phragmocone. These bullae have a conspicuous forward curvature. On some individuals, the bullae rise into bullate tubercles on the body chambers (pl. 4, figs. 2,5). The bullae or tubercles persist to the aperture but weaken there (pl. 3, fig. 8).

Most of the specimens in the two large collections are uncrushed phragmocones. A few specimens have complete or nearly complete body chambers, but these are usually somewhat crushed or distorted probably due to the work of predators. The aperture is fairly rounded and has a slight ventral bulge paralleling the course of the ribs. All ribbing weakens near the aperture (pl. 3, fig. 8).
Diameter of the shell at the base of the body chamber could be determined on 44 specimens in the two large collections. These measurements, summarized in a histogram (fig. 3), do not show a clear-cut separation into two growth sizes as would be anticipated for sexual dimorphism. The adults in these collections range in diameter from 115 to $205 \mathrm{~mm}$. A smaller adult (pl. 4 , figs. $1-3), 91 \mathrm{~mm}$ in diameter, is present in a collection from another locality (fig. 1, loc. 10).

A large collection from north-central Colorado (fig. 1, locs. 39, 40), consisting of 51 specimens suitable for one or more measurements, includes many juveniles that have body chambers (pl. 6, figs. 4-6, 10-12). The first 


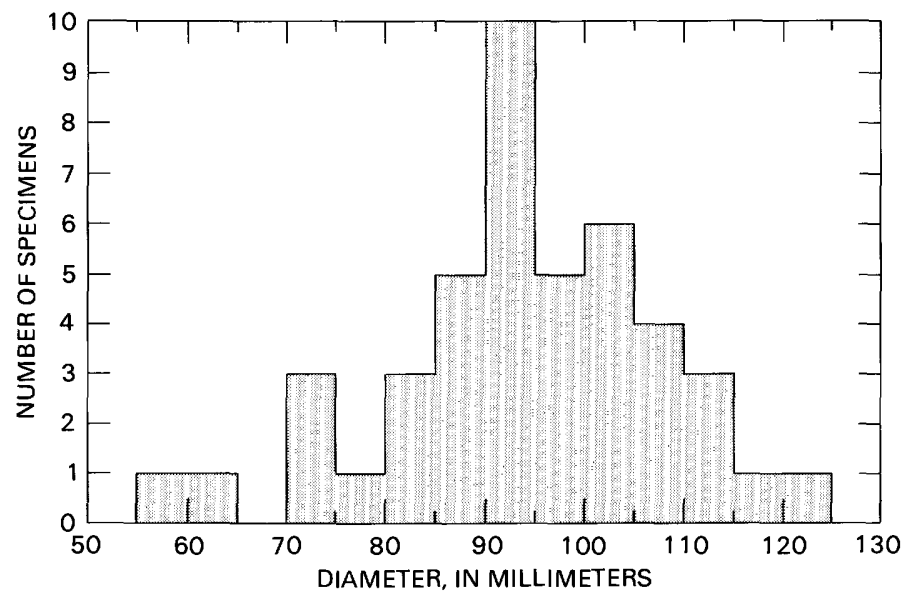

FIGURE 3.-Histogram showing range in diameter at base of body chamber of 44 specimens of Rhaeboceras halli (Meek and Hayden) from the Bearpaw Shale at USGS Mesozoic localities D783 and D10234 (fig. 1, locs. 24,17 , respectively).

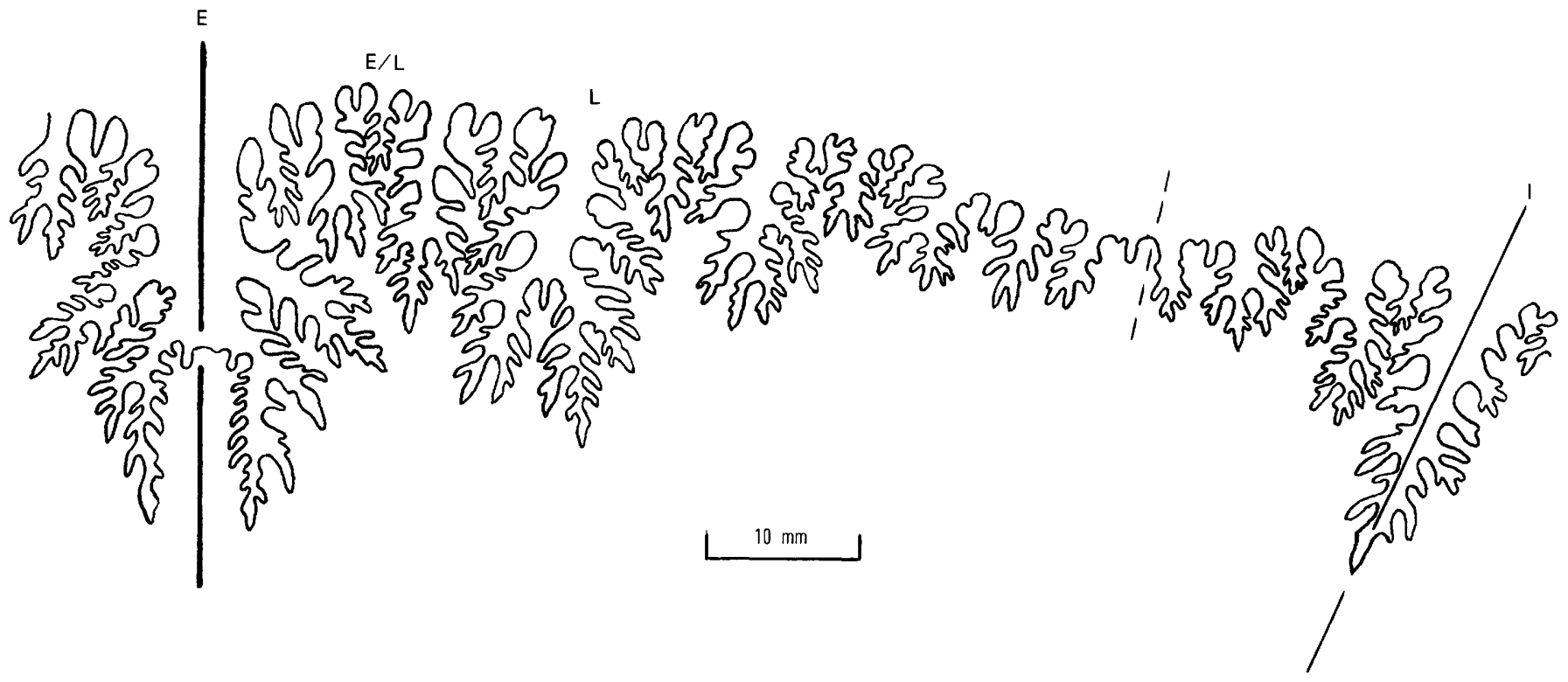

Figure 4.-Suture, nearly twice natural size, of a specimen of Rhaeboceras halli (Meek and Hayden) at a diameter of $80 \mathrm{~mm}$ from the Bearpaw Shale at USGS Mesozoic locality D5675 (fig. 1, loc. 19). The venter, dorsum, and umbilical seam are indicated by the heavy, light, and dashed lines, respectively. Hypotype USNM 413038.

two or three whorls are smooth, and ribbing does not become discernible until the shells attain a diameter between 5.5 and $8 \mathrm{~mm}$. Both primaries and secondaries appear at about the same diameter and cross the venter with moderate forward arching. On some individuals, flattening of the ribs on the venter is conspicuous on the inner whorls of the phragmocone. Ribbing near the aperture on adult specimens may be weakened and crowded. One specimen (unfigured hypotype USNM 413100) has a nearly smooth band $18 \mathrm{~mm}$ long at the aperture.
The suture of $R$. halli is quite digitate (fig. 4). Meek and Hayden (1856, p. 70) described the external suture in considerable detail, and Riccardi (1983, text figs. 32-34) illustrated the sutures of the types of $R$. halli and $R$. opalus as well as another example of $R$. halli. Discussion.-Riccardi $(1983$, p. 34$)$ has pointed out that Ammonites opalus Owen (1852, p. 579, pl. 8, figs. $6,6 \mathrm{a}, 6 \mathrm{~b}$ ) is a phragmocone of Rhaeboceras halli, but that "As Owen's name has not been used since its inception, whereas Meek's has been repeatedly quoted and is considered to represent the type species of 
Rhaeboceras Meek $* * *$ it is appropriate to follow Art. $23 \mathrm{~b}$ of the ICZN and to regard 'Ammonites opalus' as nomen oblitum." This conclusion is accepted herein. Owen's illustrations are reproduced here (pl. 1, figs. 1, 2). The type specimen, which is at the Field Museum of Natural History, Chicago, has been well illustrated by Riccardi (1983, pl. 13, figs. 1-4).

Rhaeboceras albertense (Warren, 1930, p. 23, pl. 2, figs. 1, 2; pl. 4, fig. 2) may be a stout variant of $R$. halli that has fewer ribs. Riccardi $(1983$, p. 40,41$)$ noted the possibility that $R$. albertense and $R$. halli may represent extreme morphologic variants of a single species. However, in the large collections of $R$. halli at hand (D783 and D10234), there are no specimens that quite match the holotype of $R$. albertense in its stoutness (pl. 9 , figs. 1-3). Until a large population of $R$. albertense from the type area is available for study, it seems advisable to recognize the two species.

Occurrence.-Rhaeboceras halli has been collected at many localities between north-central Colorado and the United States-Canada boundary. All occurrences in Montana are in the Bearpaw Shale (fig. 1, locs. 5, 7, 8, 10-19, 21-25, 27-30) in the zone of Baculites jenseni Cobban. In Wyoming, $R$. halli has been found at the base of the Lewis Shale north of Casper (fig. 1, loc. 32) and in the upper part of the Pierre Shale in the Black Hills area (fig. 1, locs. 31, 33). Farther south, $R$. halli occurs in the Pierre Shale near Walden, Colo. (fig. 1, loc. 36) and in the Richard Sandstone Member of the Pierre Shale in the Fort Collins area in northern Colorado (fig. 1 , locs. $38,41,42$ ).

\section{Rhaeboceras halli (Meek and Hayden), noded variant}

Plate 5, figures 1, 2; plate 13 , figures $2-5$

Types.-Figured hypotype USNM 413037, from the Bearpaw Shale about $16 \mathrm{~km}$ north-northeast of Melstone in the SW1/4 $\mathrm{SW}^{1 / 4}$ sec. 11, T. 11 N., R. 31 E., Rosebud County, Mont. Figured hypotype USNM 413025, from the Bearpaw Shale in the NW $1 / 4$ sec. 24, T. 12 N., R. 31 E., Rosebud County, Mont. Unfigured hypotypes USNM 413101, 413102.

Description.-A most unusual specimen of Rhaeboceras (pl. 13, figs. 2-5) was collected from the Bearpaw Shale (fig. 1, loc. 27) by Mr. Robert H. Feldman, Billings, Mont., and kindly donated by him to the U.S. Geological Survey. The specimen consists of a moderately stout phragmocone $110.5 \mathrm{~mm}$ in diameter with an umbilical ratio of 0.13 . A bit of the body chamber is attached. What makes the specimen so unusual is the presence of ventrolateral tubercles. These arise a little below the last quarter whorl of the phragmocone and disappear at the base of the body chamber. There are five bullate to nodate tubercles matched on each side of the venter. Fourteen long, arcuate umbilical bullae are present on the outer whorl of the phragmocone. Ribbing is unusually weak and effaced in places. Ribs crossing the venter are of irregular height and spacing and difficult to count; there are about 100 on the outer whorl. Irregular ribbing like this is present on some specimens of $R$. halli from other localities (pl. 5, figs. 3,5 ), and occasional specimens have effaced ribbing (pl. 3, fig. 4).

Another specimen (pl. 5, figs. 1, 2) from a nearby locality (fig. 1, loc. 24) consists of part of a phragmocone $71 \mathrm{~mm}$ in diameter that has 4 nodate ventrolateral tubercles on the older part of the outer whorl. Two to five nontuberculate ribs separate the tuberculate ones.

A third noded variant (unfigured hypotype USNM 413101) was collected with $R$. burkholderi Cobban, $n$. sp., at its type locality (fig. 1, loc. 20). The specimen consists of the basal part of a body chamber that has several blunt bullate ventrolateral tubercles.

A fourth specimen (unfigured hypotype USNM 413102), from much farther south (fig. 1, loc. 39), is the younger part of the outer whorl of a phragmocone that has 3 low, bullate ventrolateral tubercles separated by 1 to 5 nontuberculate ribs.

Occurrence.-All noded specimens were associated with normal $R$. halli. The rarity of the noded form is emphasized by the presence of only one specimen among the 116 normal $R$. halli collected from the Bearpaw Shale at USGS Mesozoic locality D783 (fig. 1, loc. 24). There are no noded specimens in the larger collection of 124 specimens of $R$. halli from the Bearpaw Shale at USGS Mesozoic locality D10234 (fig. 1, loc. 17). The remarkable noded specimen collected by Mr. Feldman (pl. 13, figs. 2-5) is from the same stratigraphic position as that of D783 but from a locality about $8 \mathrm{~km}$ farther south (fig. 1, loc. 27). The fragment of a noded specimen from the type locality of $R$. burkholderi, $\mathrm{n}$. sp., is from $204 \mathrm{~m}$ above the base of the Bearpaw Shale at USGS Mesozoic locality D5663 (fig. 1, loc. 20). Among the 20 larger specimens of $R$. halli from the Richard Sandstone Member of the Pierre Shale of northern Colorado, only one has ventrolateral tubercles.

\section{Rhaeboceras mullananum (Meek and Hayden)}

Plate 7, figures 7,8

1862. Ammonites mullananus Meek and Hayden, p. 23.

1876. Ammonites? mullananus (Meek and Hayden). Meek, p. 607, pl. 8, figs. 1a-c.

1894. Scaphites mullananus (Meek and Hayden). Stanton, p. 187, pl. 45, figs. 2-4 [1893 imprint].

1898. Scaphites mullananus Meek and Hayden. Logan, p. 477, pl. 105 , figs. 2-4.

1900. Scaphites mullananus Meek and Hayden. Herrick and Johnson, pl. 46, figs. 2-4. 
1925. Scaphites mulleanus (sic) (Meek and Hayden). Diener, p. 201. 1927. Scaphites mullananus (Meek and Hayden). Reeside, p. 31. Not 1905. Scaphites mullananus (Meek and Hayden). Smith, text figs. 1 (8), 3 (11).

Type.-Holotype USNM 1924 from Chippewa Point on the Missouri River in north-central Montana.

Diagnosis.-A coarse-ribbed, stout species that is known only by the holotype.

Description.-Rhaeboceras mullananum was founded on two fragments of a large phragmocone whose dimensions were given by Meek and Hayden as "its greatest diameter 4 inches, and 2.57 inches in breadth at the widest part of the outer whorl." The two fragments are preserved at the National Museum of Natural History in Washington, D.C. (USNM 1924). A large piece is missing between the two fragments. Meek (1876, pl. 8, figs. 1a-c) illustrated only the smaller fragment, which represents the inner whorls. Views of a plaster cast of the two fragments, which have the missing piece filled by plaster, are shown on plate 7 (figs. 7, 8).

The species is very stout and has a whorl section that is wider than high. Ribbing is rectiradiate to slightly prorsiradiate on the flanks and arched forward a little on the venter. All ribs are coarse, rounded, and sparse. Ten primary ribs and 26 secondary ribs are present on the last half of the inner whorls at a diameter of about $68 \mathrm{~mm}$. Primaries are bullate on the umbilical shoulder.

The external suture, shown by Meek (1876, pl. 8, fig. 1c), was poorly drawn. The lobes appear to be trifid although Meek stated that they were asymmetrically bifid. The first lateral lobe, visible on the plaster cast, is rather symmetrically bifid and much like that of $R$. halli in its complexity.

Discussion.-Specimens comparable to the holotype of $R$. mullananum are absent in the collections of Rhaeboceras examined by me. The type was said to have come from "Chippewa Point, near Fort Benton, on the Upper Missouri; Fort Benton Group of the Nebraska Cretaceous series" (Meek and Hayden, 1862, p. 22). These authors gave this locality as "some twenty odd miles below Fort Benton." Meek and Hayden's types of Scaphites vermiformis and S. ventricosus were also said to have come from this locality. Assuming the 20-odd miles were measured as river miles, Chippewa Point should lie in the Coniacian to Santonian age upper part of the Marias River Shale (Colorado Shale of Pierce and Hunt, 1937, pl. 43). The S. vermiformis and $S$. ventricosus would certainly fit this locality and stratigraphic position, but the Rhaeboceras mullananum presents a problem inasmuch as all other occurrences of this genus are from the much younger Bearpaw and Pierre Shales. The fossils described by Meek and Hayden in their 1862 paper were collected by John Pearsall, naturalist for Lieut. John Mullan's expedition that was seeking a wagon road route from the upper reaches of the Missouri River to the Pacific Ocean. Meek and Hayden (1862, p. 21) noted that "The collections containing the fossils described in this paper, were obtained along the Missouri River at various localities between Fort Benton and points 140 to 150 miles below the Fort. The new forms here for the first time made known, are all labelled 'Chippewa Point.'" The possibility thus exists that the type of $R$. mullananum, although labelled Chippewa Point, could have come from the Bearpaw Shale which crops out less than 150 miles below Fort Benton. On the other hand, inasmuch as Meek and Hayden's species cannot be matched with anything in the collections of Rhaeboceras examined, $R$. mullananum could be from Chippewa Point as stated and possibly of Santonian age.

The Scaphites mullananus, illustrated by Smith (1905, p. 641, fig. 8; p. 645, fig. 11), represents specimens of Ponteixites robustus Warren (1934, p. 95, pl. 3, figs. 1-4). Smith's specimens came from the upper part of the Pierre Shale (zone of Baculites baculus Meek and Hayden) on the Cedar Creek anticline in eastern Montana.

\section{Rhaeboceras subglobosum (Whiteaves)}

Plate 7, figures 1, 3; plate 8, figures 3-5; plate 9, figures 4-6; plate 10

1885. Scaphites subglobosus Whiteaves, p. 52, pl. 7, fig. 3; pl. 8, figs. 1, 1a (not 2, 2a).

1917. Scaphites subglobosus Whiteaves. Dowling, p. 32, pl. 31, figs. 1, 1a (not 2, 2a).

1925. Scaphites subglobosus Whiteaves. Diener, p. 203.

1927. Acanthoscaphites? subglobosus (Whiteaves). Reeside, p. 34. 1933. Scaphites subglobosus Whiteaves. Elias, p. 315.

1940. Rhaeboceras subglobosus (Whiteaves). Landes, p. 176.

1940. Rhaeboceras whiteavesi Landes, p. 174, pl. 6, fig. 9; pl. 7, fig. 4; pl. 8.

1983. Rhaeboceras subglobosus (Whiteaves). Riccardi, p. 40, pls. 19-21; pl. 22, fig. 1 ; pl. 23 , figs. 1-3; text figs. 50-56.

Types.-Lectotype GSC 5339 from the Bearpaw Shale of southern Saskatchewan figured by Whiteaves (1885, pl. 7, fig. 3 ; pl. 8, figs. 1, 1a), by subsequent designation of Elias (1933, p. 315). Hypotypes USNM 413039-413043 from the Bearpaw Shale of east-central Montana.

Diagnosis.-A large, stout species that has depressed whorl sections and fairly dense ribbing.

Description.-Whiteaves described and illustrated two phragmocones, a small one that has umbilical and ventrolateral tubercles and a large one without tubercles. Elias (1933, p. 315) assigned the small noded specimen to Scaphites plenus Meek and Hayden. Inasmuch as Whiteaves didn't designate a holotype, the large nontuberculate phragmocone became the lectotype by Elias' emendation. 
Rhaeboceras subglobosum is characterized by its large size and great stoutness; the whorls are wider than high. The lectotype is a little more densely ribbed than indicated by Whiteaves' drawing, and on the inner half of the flanks, the ribs are separated into primaries and secondaries instead of ribs of equal size and length as shown by Whiteaves. As on other species of Rhaeboceras, only the primaries extend into the umbilicus, and they are slightly bullate on the umbilical shoulder. A plaster cast of the holotype reveals a ventral rib count of 25 per half whorl at a diameter of $68 \mathrm{~mm}$ and 30 per half whorl at a diameter of $97 \mathrm{~mm}$.

Whiteaves (1885, pl. 8, fig. 1a) illustrated part of the suture of the lectotype. This suture and that of the holotype of $R$. halli, figured by Meek (1876, pl. 24, fig. $3 c$; text fig. 64), are very similar.

Discussion.-Rhaeboceras whiteavesi Landes (1940, p. 174, pl. 6, fig. 9; pl. 7, fig. 4; pl. 8) has been shown by Riccardi $(1983$, p. 41$)$ to be the same species as $R$. subglobosum. The holotype of $R$. whiteavesi (pl. 9, figs. 4-6) came from the Bearpaw Shale in Alberta, Canada.

Occurrence.-Whiteaves' type came from the Bearpaw Shale on Old Wives Creek (now Notukeu Creek) in T. 10, R. 11, W. 3d mer., southwestern Saskatchewan. The species is uncommon in the Western Interior of the United States. A few specimens have been found in the Bearpaw Shale in central and north-central Montana (fig. 1, locs. 1, 3, 6, 26). Fragments of two large distorted specimens were collected from the Larimer Sandstone Member of the Pierre Shale in north-central Colorado, where they were associated with Baculites reesidei Elias (fig. 1, locs. 37, 43).

Rhaeboceras subglobosum (Whiteaves), nodod variant

Plate 12, figures 4-7; plate 14

Types.-Hypotype USNM 413043, from the Bearpaw Shale at USGS Mesozoic locality D12735 in Phillips County, Mont. (fig. 1, loc. 9); hypotype USNM 413042, from the Pierre Shale in Laramie County, Wyo. (fig. 1, loc. 35).

Description.-Two stout specimens of Rhaeboceras subglobosum are unusual in that both have ventrolateral tubercles on the body chamber. The larger specimen (pl. 14) is a magnificent macroconch that was donated to the U.S. Geological Survey by Mr. Howard Ehrle, Miles City, Mont. This specimen, $153 \mathrm{~mm}$ long, is missing a part of the outer whorl of the phragmocone and a small piece of the body chamber. These missing parts were restored in plaster by Mr. Ehrle. The phragmocone has a fairly wide umbilicus (ratio of about 0.20 ), and the outer whorl is broader than it is high. Ornament on the last half of the outer whorl consists of 9 narrow, curved, prorsiradiate umbilical bullae and about 30 ribs. The body chamber, which occupies threefourths of a whorl, is broken a little but not distorted much. It has 13 narrow umbilical bullae and 70 narrowly rounded, prorsiradiate ribs that cross the venter. Most ribs arise from the umbilical bullae or from low on the flank. Conspicuous bullate to nodate ventrolateral tubercles are present on the middle one-half of the phragmocone. These arise either from single flank ribs or from a pair of flank ribs, and they are usually connected across the venter by 2 or 3 ribs. The aperture is normal; it is not preceded by closely spaced ribs.

The smaller specimen (pl. 12, figs. 4-7) which may be a microconch, is an incomplete body chamber that encloses part of the phragmocone. The specimen is unusual in that two widely spaced pairs of ventrolateral tubercles are present on the body chamber. The specimen, $111 \mathrm{~mm}$ in length, includes the last one-half of a rather small adult body chamber that has a normal aperture preceded by a belt of closely spaced ribs (pl. 12, figs. 6, 7). Ribs on the rest of the body chamber are narrow, high, and fairly sharp. Some arise from sharp, narrow umbilical bullae, and others arise farther out on the flank. The two pairs of sharp, bullate ventrolateral tubercles lie on ribs that are separated by 10 nontuberculate ribs. The enclosed part of the phragmocone (pl. 12, figs. 4-6) includes almost one-half of the older part of the outer whorl and has a diameter of 63 $\mathrm{mm}$. Its whorl section is higher than wide with a wellrounded venter and flat flanks. Umbilical bullae are narrow and closely spaced. A primary rib arises from each bulla, and every two primaries are separated by a secondary rib farther out on the flank. On crossing the venter, all ribs are coarse and well-rounded and about the size of the interspaces. There are no ventrolateral tubercles.

Occurrence.-The smaller noded variant was collected at USGS Mesozoic locality D1382 in southeastern Wyoming (fig. 1, loc. 35). Here the specimen was found in a sandy limestone concretion in the Pierre Shale 15 $\mathrm{m}$ above a unit of sandstone that may be the equivalent of the Larimer Sandstone Member of the Pierre Shale of areas farther south in northern Colorado. The specimen is probably from the zone of Baculites reesidei Elias. The large macroconch (pl. 14), which was not collected by Mr. Ehrle, does not have good locality data; it is from the Bearpaw Shale somewhere in the Telegraph Creek area in southeastern Phillips County, Mont.

\section{Rhaeboceras coloradoense Cobban, n. sp.}

Plate 6, figures 16-21; text figure 5

Types.-Holotype USNM 413044 from the Richard Sandstone Member of the Pierre Shale at USGS Mesozoic locality 16093 on the south bank of Reservoir 
No. 3 in the $\mathrm{N}^{1} 1 / 2 \mathrm{SE}^{1 / 4}$ sec. 19 , T. 9 N., R. 68 W., Larimer County, Colo. Paratype USNM 413045 from the Richard Sandstone Member at the same locality.

Diagnosis.-A wide umbilicus, robust whorls, and coarse ribbing characterize this moderate-sized species.

Description.-The holotype (pl. 6, figs. 19-21), a complete adult, has a maximum diameter of $110.5 \mathrm{~mm}$ and a breadth of $45.5 \mathrm{~mm}$. The body chamber occupies threefourths of the last whorl. The deflection of the body chamber away from the regular curvature of the phragmocone produces a wide umbilicus whose ratio is 0.25 at a diameter of $77.4 \mathrm{~mm}$ and 0.29 at $102.8 \mathrm{~mm}$. In cross section, the body chamber is slightly wider than high and attains its greatest breadth at the umbilical shoulder; the flanks are broadly rounded, and the venter is more narrowly rounded. The phraginocone of the holotype, however, has its outer whorl slightly higher than wide and flattened flanks.

Ribbing on the holotype is prorsiradiate, slightly flexuous on the phragmocone, and straight on the body chamber. Secondary ribs are conspicuous on the phragmocone where they curve forward and are a little bullate on the umbilical shoulder; they number 17 on the last whorl. On the body chamber, the bullae rise into nine bullate tubercles. Secondary ribs are present on the outer half of the flanks of the phraginocone, but on the body chamber, the secondaries tend to lengthen and rise nearer the umbilical shoulder. Fifty-five ribs cross the venter on the last complete whorl of the holotype.

The suture is typical of the genus but not as digitate as that of $R$. halli. The external suture of the holotype is shown in figure 5.

Discussion.-Rhaeboceras coloradoense differs from the associated $R$. halli in having a wider umbilicus and fewer ribs. The species is known only from northern Colorado where it occurs sparingly in the Richard Sandstone Member of the Pierre Shale (zone of Baculites jenseni Cobban) at USGS Mesozoic locahty 16093 (fig. 1, loc. 39).

Rhaeboceras coloradoense Cobban, n. sp., noded variant

Plate 7, figures 4-6

Type.-Paratype USNM 413046, from the Richard Sandstone Member of the Pierre Shale at USGS Mesozoic locality 22921 on the south bank of Reservoir No 3 in the N1/2SE1/4 sec. 19, T. 9 N., R. 68 W., Larimer County, Colo.

Description.-The specimen is an adult that has a length (height) of only $60.7 \mathrm{~mm}$. Its wide umbilicus has a width of $8.7 \mathrm{~mm}$ at a diameter of $44 \mathrm{~mm}$ (ratio of 0.20 ). Only part of the outer whorl of the phragmocone is preserved; it has a whorl section that is higher than it is wide with rounded venter and flattened flanks. Ornament on the phraginocone consists of prorsiradiate

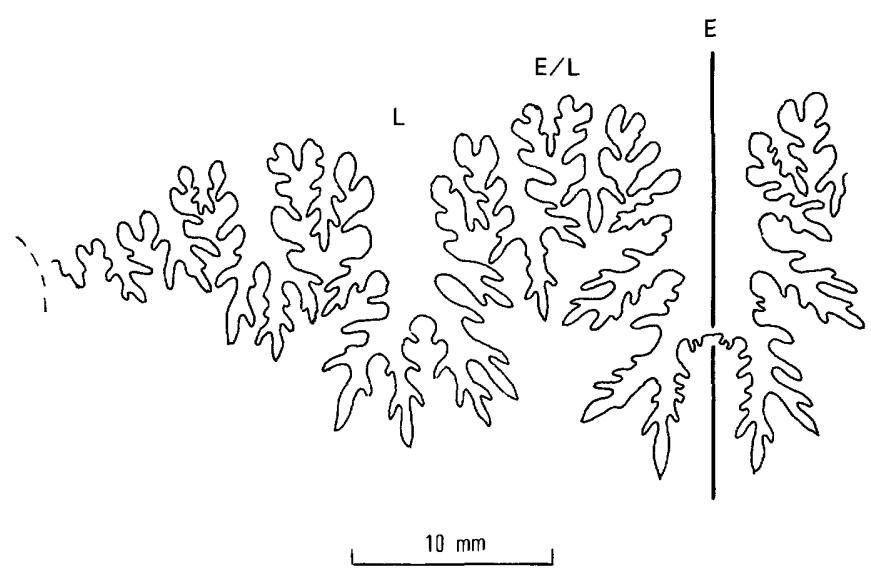

FIGURE 5.-Third from last external suture of the holotype of Rhaeboceras coloradoense Cobban n. sp. (pl. 6, figs. 19-21), from the Richard Sandstone Member of the Pierre Shale at USGS Mesozoic locality 16093 (fig. 1, loc. 39). USNM 413044.

flexuous primary ribs that arise from narrow umbilical bullae and 3 or 4 secondary ribs between the primaries. All ribs are high, rounded, and equal sized on crossing the venter and separated by interspaces that are the same size as the ribs. The body chamber, which occupies three-fourths of a whorl, has a whorl section that is higher than wide on the older part and wider than high on the younger part. Eleven narrow umbilical bullae are present on the body chamber. Each gives rise to a sharp, flexuous, prorsiradiate primary rib, and these ribs are separated by 3 to 4 secondary ribs on the older part of the body chamber and 1 to 3 secondaries on the younger part. Two ribs on the older part of the body chamber have sharp, bullate ventrolateral tubercles on one side of the shell. The aperture, which follows the trend of the ribs, is not preceded by close spacing of ribs.

Occurrence. - The specimen was collected at the same locality as that of the holotype of Rhaeboceras coloradoense, n. sp., which is in the zone of Baculites jenseni Cobban. The specimen is interpreted as a noded microconch of $R$. coloradoense, with the holotype representing the macroconch.

Rhaeboceras burkholderi Cobban, n. sp.

Plate 11, figures 1-4; text figure 6

Type.-Holotype USNM 413047, from the Bearpaw Shale at USGS Mesozoic locality D5663 about $11 \mathrm{~km}$ east of Mosby in the NW1/4 sec. 10, T. 14 N., R. 31 E., Garfield County, Mont.

Name.-This distinctive species is named in honor of Robert E. Burkholder of the U.S. Geological Survey, who greatly aided the author in the field and in the laboratory for many years. Mr. Burkholder also collected the holotype of the species. 
Diagnosis.-A compressed species that has a body chamber with flattened flanks and a slightly flattened venter bordered by bullate tubercles or by ribs accentuated along the ventrolateral border.

Description.-The holotype (pl. 11, figs. 1-4) is a nearly complete adult that has a length of $75.5 \mathrm{~mm}$ and a breadth of $26.5 \mathrm{~mm}$. Its umbilical ratio is 0.16 at a diameter of $53.3 \mathrm{~mm}$. The body chamber includes 85 percent of the last complete whorl. As in other species of Rhaeboceras, the body chamber is deflected a little from the regular curvature of the phragmocone. Both the body chamber and outer whorl of the phragmocone have flattened flanks and whorl sections that are considerably higher than wide.

Ribbing on the holotype is sparse, prorsiradiate, and somewhat flexuous. Primary ribs on the last half whorl of the phragmocone extend from the umbilicus across the flanks and venter. On the outer part of the flank, a secondary rib appears and crosses the venter between two primaries. All ribs are of equal strength on the venter. About 20 or 21 ventral ribs are present on the last half whorl of the phragmocone. Ribbing on the body chamber is a little more closely spaced than that on the phragmocone, the secondary ribs are longer, and the primaries rise from bullate tubercles on the umbilical shoulder. All primaries and most secondaries rise into bullate tubercles on the ventrolateral shoulder on the older two-thirds of the body chamber. The tubercles gradually weaken and disappear on the younger part. At the point where the tubercles weaken, the ribs begin to arch forward on crossing the venter as they do on the outer whorl of the phragmocone. Where the ventrolateral tubercles are well developed, the ribs trend straight across the venter except for a small area on the holotype that has ventral ribs arranged in a zigzag pattern. The suture of the holotype is rather simple (fig. 6).

Discussion.-Rhaeboceras burkholderi is an uncommon species. A slightly smaller and more densely ribbed adult from southern Saskatchewan, identified as Scaphites abyssinus Morton by Whiteaves (1885, p. 51), is probably $R$. burkholderi. A plaster cast of the Canadian specimen (GSC 5338) is in the reference collections of the U.S. Geological Survey, Federal Center, Denver, Colo.

Occurrence.-The type is from a brown-weathering ferruginous, limestone concretion $204 \mathrm{~m}$ above the base of the Bearpaw Shale at USGS Mesozoic locality D5663 (fig. 1, loc. 20). Part of a specimen of Rhaeboceras halli was found in these concretions as well as a fragment of the noded variant. At this locality, Baculites reesidei Elias was found at $200 \mathrm{~m}$ above the base of the Bearpaw and Baculites cf. B. jenseni Cobban was found at 206-212 $\mathrm{m}$ above the base.

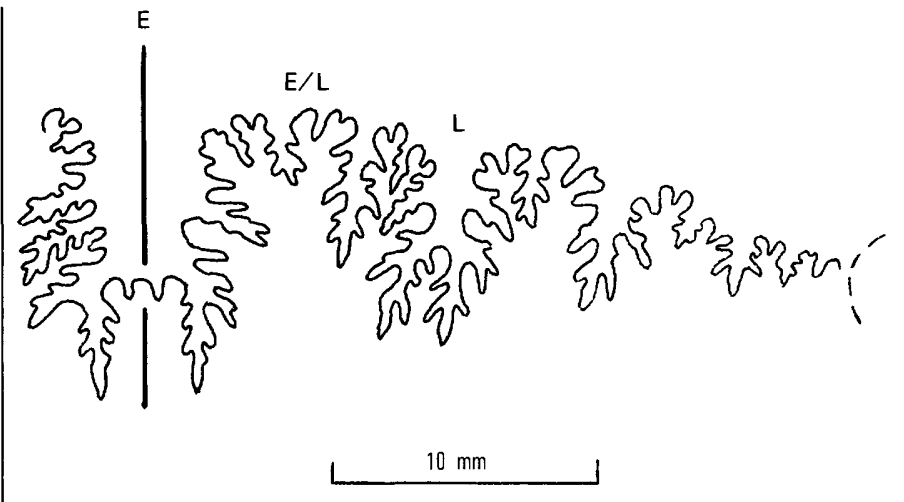

Figure 6.-Second from last external suture of the holotype of Rhaeboceras burkholderi Cobban n. sp., from the Bearpaw Shale at USGS Mesozoic locality D5663 (fig. 1, loc. 20). USNM 413047.

\section{Rhaeboceras cf. R. burkholderi Cobban, n. sp.}

Plate 11, figures 7,8

Type.-Figured specimen USNM 413048 from the Bearpaw Shale at USGS Mesozoic locality D5663 about $11 \mathrm{~km}$ east of Mosby in the NW1/4 sec. 10, T. 14 N., R. 31 E., Garfield County, Mont. (same locality as that of the holotype of Rhaeboceras burkholderi, n. sp.)

Description.-This specimen is a nearly complete adult $128 \mathrm{~mm}$ in length. The slender phragmocone, which is uncrushed, has a piece missing at its larger end, where the diameter of the shell is estimated at $66 \mathrm{~mm}$ with an umbilical ratio of about 0.12 . The phragmocone has flattened flanks and a narrowly rounded venter. Ornament on the outer whorl of the phragmocone consists of 9 prorsiradiate umbilical bullae and 38 ribs that cross the venter. The crushed body chamber occupies three-fourths of a whorl. Ornament on it consists of 9 prorsiradiate umbilical bullae and about 48 ribs that cross the venter. Some of the ribs are accentuated a little along the ventrolateral shoulder.

Discussion.-The phragmocone of this specimen is like that of $R$. halli, whereas the body chamber resembles that of $R$. burkholderi in its coarse and sparse ribbing. If additional collections prove that this individual is $R$. burkholderi, then the specimen could be interpreted as a macroconch because it is about twice as large as the holotype of $R$. burkholderi (the microconch).

\section{REFERENCES CITED}

Bayle, E., 1878, Fossiles principaux des terrains [atlas], Part 1 of Volume 4, Explication de la carte géologique de la France: Paris, Imprimerie Nationale, pls. 1-158 [text never published].

Cobban, W.A., 1951 [1952], Scaphitoid cephalopods of the Colorado group: U.S. Geological Survey Professional Paper 239, 42 p., 21 pls. 
1962, New baculites from the Bearpaw Shale and equivalent rocks of the Western Interior: Journal of Paleontology, v. 36, no. 1, p. $126-135$, pls. $25-28$.

Diener, Carl, 1925, Ammonoidea neocretacea, Part 29 of Animalia, [Part] 1 of Diener, Carl, ed., Fossilium catalogus: Berlin, W. Junk, $244 \mathrm{p}$.

Dowling, D.B., 1917, The southern plains of Alberta: Geological Survey of Canada Memoir 93, 200 p., 35 pls.

Elias, M.K., 1933, Cephalopods of the Pierre formation of Wallace County, Kansas, and adjacent area: Lawrence, Kans., Kansas University Science Bulletin, v. 21, no. 9, p. 289-363, pls. 28-42.

Gill, J.R., and Cobban, W.A., 1966, The Red Bird section of the Upper Cretaceous Pierre Shale in Wyoming, with a section on A new echinoid from the Cretaceous Pierre Shale of eastern Wyoming, by P.M. Kier: U.S. Geological Survey Professional Paper 393-A, $73 \mathrm{p}$.

Hayden, F.V., 1859, Catalogue of the collections in geology and natural history obtained by the expedition under command of Lieut. G.K. Warren, in Warren, G.K., Preliminary account of explorations in Nebraska and Dakota in the years 1855-56-57: U.S. War Department Annual Report 1858 (U.S. 35th Congress, Second Session, House Executive Document 2), p. 673-705.

Herrick, C.L., and Johnson, D.W., 1900, The geology of the Albuquerque sheet: Granville, Ohio, Denison University Scientific Laboratories Bulletin, v. 11, art. 9, p. 175-239, pls. 27-49; Albuquerque, N. Mex., New Mexico University Bulletin, v. 2, 67 p., 22 pls.

Jeletzky, J.A., 1968, Macrofossil zones of the marine Cretaceous of the western interior of Canada and their correlation with the zones and stages of Europe and the western interior of the United States: Geological Survey of Canada Paper 67-72, $66 \mathrm{p}$.

Jensen, F.S., and Varnes, H.D., 1964, Geology of the Fort Peck area, Garfield, McCone, and Valley Counties, Montana: U.S. Geological Survey Professional Paper 414-F, 49 p.

Kilian, W., and Reboul, P., 1909, Les céphalopodes néocrétacés des Îles Seymour et Snow Hill: Wiss. Ergebnisse Schwedischen Südpolar-Expedition 1901-1903, v. 3, pt. 6, 75 p., 20 pls.

Landes, R.W., 1940, Paleontology of the marine formations of the Montana group, Pt. 2 of Geology of the southern Alberta plains: Geological Survey of Canada Memoir 221, Pub. 2453, p. 129-217, 8 pls.

Logan, W.N., 1898, The invertebrates of the Benton, Niobrara, and Fort Pierre groups: Lawrence, Kans., Kansas University Geological Survey, v. 4, p. 431-518, pls. 86-120.

Magalhães, Júlio, and Mezzalira, Sérgio, 1953, Moluscos fósseis do Brasil: Brazil Instituto Nacional Livro, ser. A, no. 4, 283 p., 94 pls.

Meek, F.B., 1864, Check list of the invertebrate fossils of North America; Cretaceous and Jurassic: Smithsonian Miscellaneous Collections $177,40 \mathrm{p}$.

Meek, F.B. 1876, A report on the invertebrate Cretaceous and Tertiary fossils of the upper Missouri country: U.S. Geological Survey of the Territories (Hayden) Report 9, 629 p., 45 pls.

Meek, F.B., and Hayden, F.V., 1856, Descriptions of new species of Gasteropoda and Cephalopoda from the Cretaceous formations of Nebraska Territory: Academy of Natural Sciences of Philadelphia Proceedings, v. 8, p. 70-72.

1860 , Systematic catalogue, with synonyma, etc., of Jurassic, Cretaceous, and Tertiary fossils collected in Nebraska, by the exploring expeditions under the command of Lieut. G.K. Warren, of U.S. Topographical Engineers: Academy of Natural Sciences of Philadelphia Proceedings 1860, p. 417-432.
1862, Descriptions of new Cretaceous fossils from Nebraska Territory, collected by the expedition sent out by the Government under the command of Lieut. John Mullan, U.S. Topographical Engineers, for the location and construction of a wagon road from the sources of the Missouri to the Pacific Ocean: Academy of Natural Sciences of Philadelphia Proceedings 1862, p. 21-28.

Naidin, D.Y., 1974, Class Cephalopoda, in Blank, M. Ya, Krymgolz, G. Ya, Naidin, D.Y., and Savchinskaya, O.V., Atlas Verkhnemelovoy Fauny Donbassa: Nedra (Moscow), p. 158-240, pls. $53-81$.

Nowak, Jan, 1912, Die Scaphiten, Pt. 2 of Untersuchungen über die Cephalopoden der oberen Kreide in Polen: Académie des Sciences de Cracovie Bulletin International, année 1911, ser. B, p. 547-589, pls. 32, 33.

Owen, D.D., 1852, Report of a geological survey of Wisconsin, Iowa, and Minnesota and incidentally of a portion of Nebraska Territory: Philadelphia, Pa., Lippincott, Grambo \& Co., 638 p., illus.

Parkinson, James, 1811, Organic remains of a former world, v. 3: London, J. Robson, 479 p., 22 pls.

Pierce, W.G., and Hunt, C.B., 1937, Geology and mineral resources of north-central Chouteau, western Hill, and eastern Liberty Counties, Montana: U.S. Geological Survey Bulletin 847-F, p. 225-270.

Reeside, J.B., Jr., 1927, The scaphites, an Upper Cretaceous ammonite group: U.S. Geological Survey Professional Paper 150-B, p. 21-40, pls. 9-11.

Riccardi, A.C., 1983, Scaphitids from the upper Campanian-lower Maastrichtian Bearpaw Formation of the western interior of Canada: Geological Survey of Canada Bulletin 354, 103 p., 26 pls.

Scott, G.R., and Cobban, W.A., 1959, So-called Hygiene Group of northeastern Colorado, in Rocky Mountam Association of Geologists Guidebook 11th Annual Field Conference, Washakie, Sand Wash, and Piceance Basins, 1959: p. 124-131.

Smith, W.D., 1905, The development of Scaphites: Journal of Geology, v. 13 , no. 7 , p. 634-654.

Spath, L.F., 1953, The Upper Cretaceous cephalopod fauna of Graham Land: Falkland Islands Dependencies Survey, Science Report no. 3,60 p., 13 pls.

Stanton, T.W., 1893 [1894], The Colorado formation and its invertebrate fauna: U.S. Geological Survey Bulletin 106, 288 p., 45 pls.

Steinmann, G., 1895, Die Cephalopoden der Quiriquina-Schichten: Neues Jahrbuch für Mineralogie, Geologie, und Palöntologie Abhandlungen, v. 10, p. 64-94, pls. 4-6.

Suess, E., 1866-70, Uber Ammoniten, pt. 1: Sitzungsberichte der Mathematisch-Naturwissenschaftlichen Classe der Kaiserlichen Akademie der Wissenschaften, v. 52, pt. 1, p. 71-89.

Warren, P.S., 1930, Three new ammonites from the Cretaceous of Alberta: Royal Society of Canada Transactions, 3d ser., v. 24, sec. 4, p. 21-26, 4 pls.

1934, Palaeontology of the Bearpaw Formation: Royal Society of Canada Transactions, $3 d$ ser., v. 28 , sec. 4, p. 81-100, 3 pls.

Whiteaves, J.F., 1885, Report on the Invertebrata of the Laramie and Cretaceous rocks of the vicinity of the Bow and Belly Rivers and adjacent localities in the North-West Territory: Geological Survey of Canada Contributions to Canadian Palaeontology, v. 1, pt. 1, 89 p., 11 pls.

Wright, C.W., 1957, Superfamily Scaphitaceae Meek [p. L228-L232], in Arkell, W.J., Kummel, Bernhard, and Wright, C.W., Mesozoic Ammonoidea, in Moore, R.C., ed., Treatise on invertebrate paleontology, Part L, Mollusca 4: New York, N.Y., and Lawrence, Kans., Geological Society of America and University of Kansas Press, p. L80-L465, text figs. 124-558. 


\section{INDEX}

[Italic page numbers indicate major references]

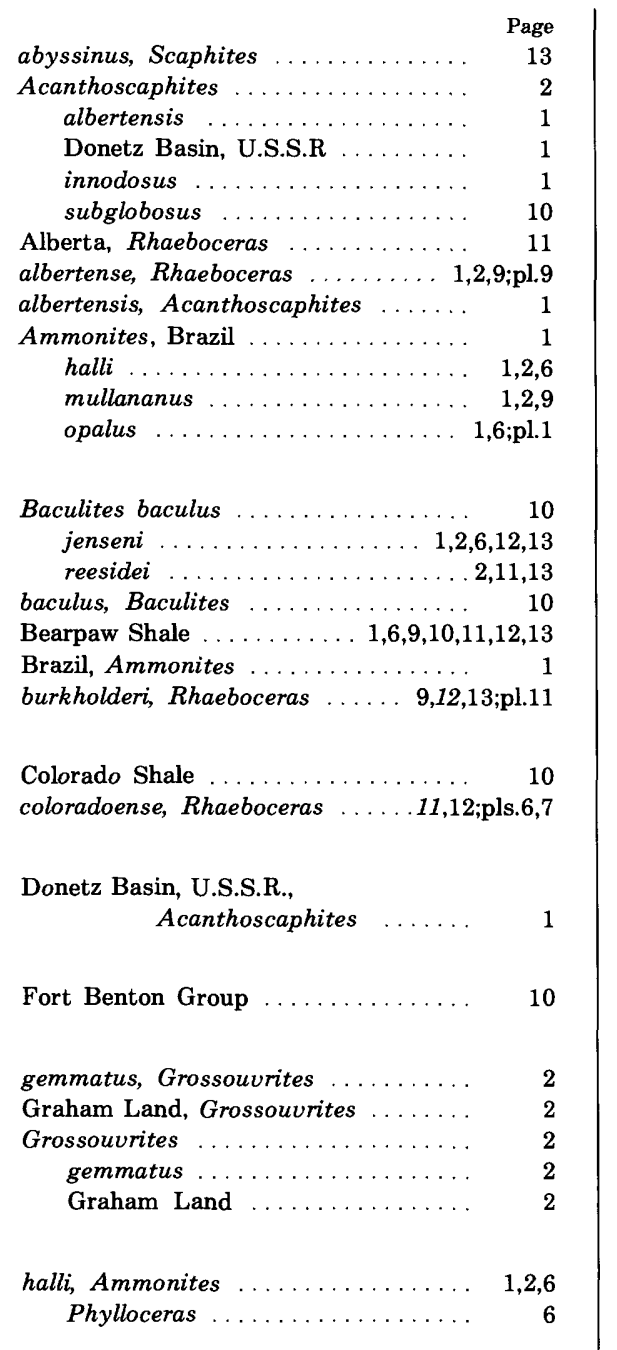

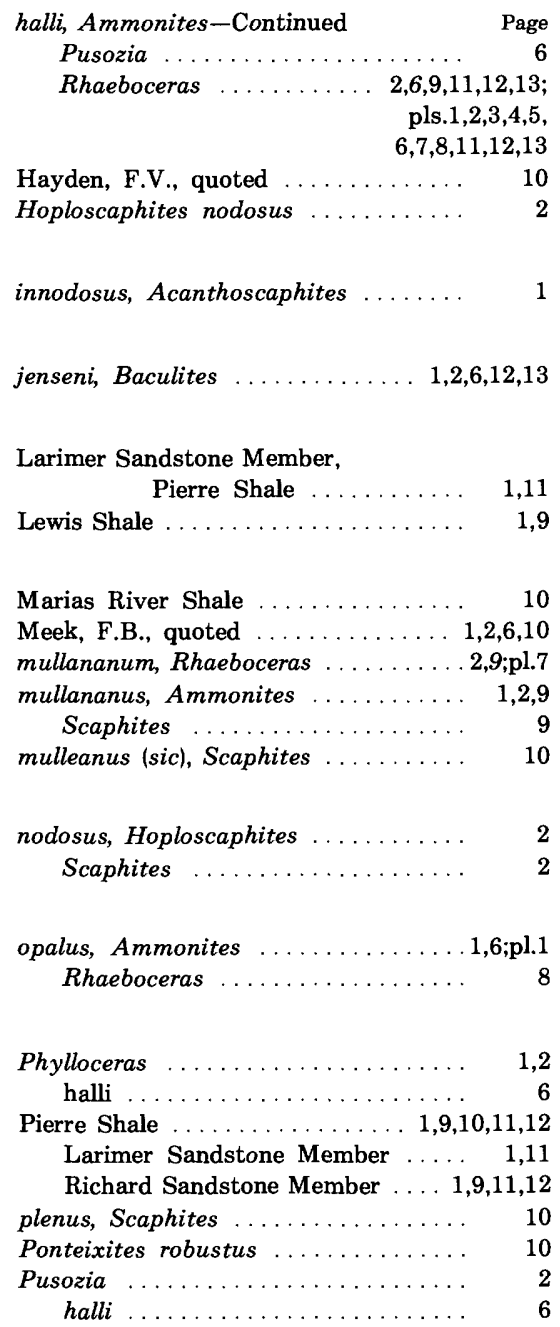

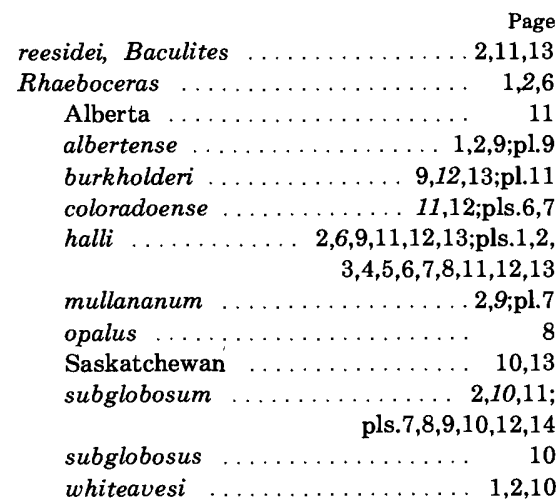

Riccardi, A.C., quoted . . . . . . . . . 8 Richard Sandstone Member, Pierre Shale 1,9,

11,12

robustus, Ponteixites ............. 10

Saskatchewan, Rhaeboceras . . . . . 10,13

Scaphites ....................

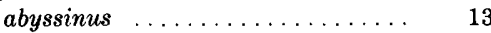
mullananus ................. 9 mulleanus (sic) .............. 10 nodosus ............... 2 plenus .................... 10 subglobosus .............. 1,10 ventricosus ................ 10 vermiformis $\ldots \ldots \ldots \ldots \ldots \ldots .10$ subglobosum, Rhaeboceras . . . . . 2,10,11 pls.7,8,9,10,12,14

subglobosus, Acanthoscaphites ..... 10 Rhaeboceras ............... 10 Scaphites ............. 1,10

ventricosus, Scaphites ........... 10 vermiformis, Scaphites $\ldots \ldots \ldots \ldots \ldots .10$

whiteavesi, Rhaeboceras . . . . . . 1,2,10 



\section{PLATES}

Contact photographs of the plates in this report are available, at cost, from the U.S. Geological Survey Library, Federal Center, Denver, CO 80225 


\section{PLATE 1}

[All figures natural size. Arrow points to base of body chamber]

FIGURES 1-12. Rhaeboceras halli (Meek and Hayden) (p. 6).

1, 2. Holotype of Ammonites opalus Owen (from Owen, 1852).

3, 7, 8. Rear, side, and front views of hypotype USNM 413012, from USGS Mesozoic locality D783 (text fig. 1, loc. 24).

4-6. Front, side, and rear views of hypotype USNM 413013, from the same locality.

9, 10. Side and rear views of hypotype USNM 413014, from USGS Mesozoic locality D10224 (text fig. 1, loc. 13).

11, 12. Front and side views of a plaster cast of the holotype USNM 384, from northern Montana. 
U.S. GEOLOGICAL SURVEY
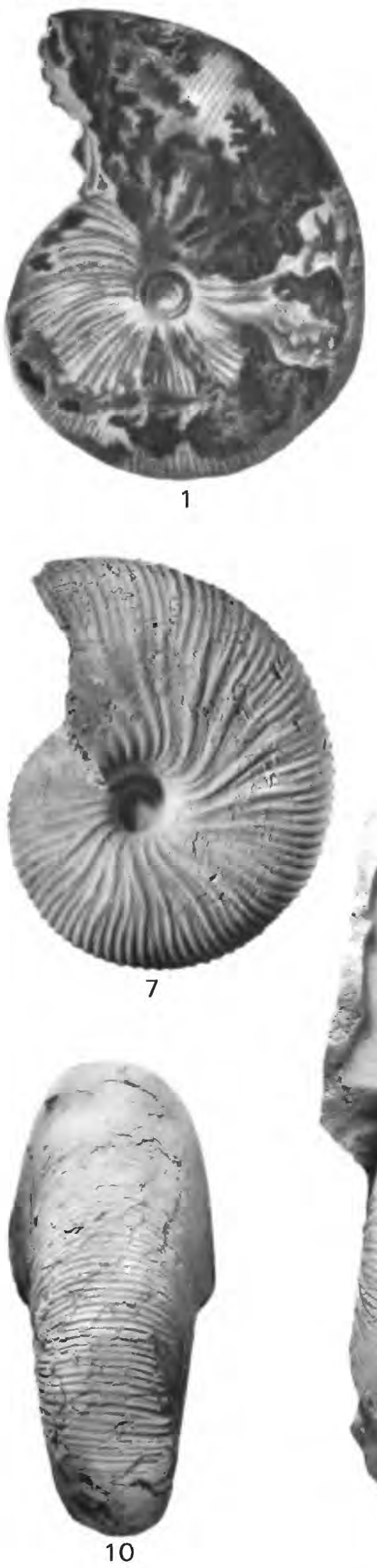
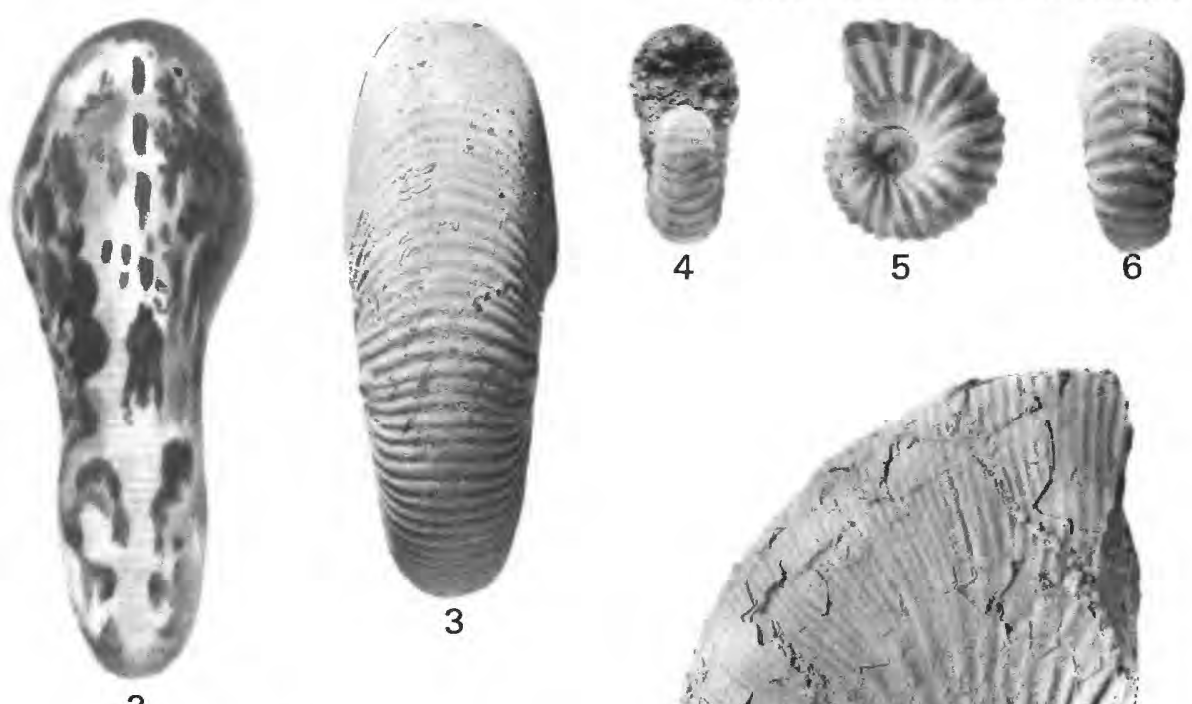

2
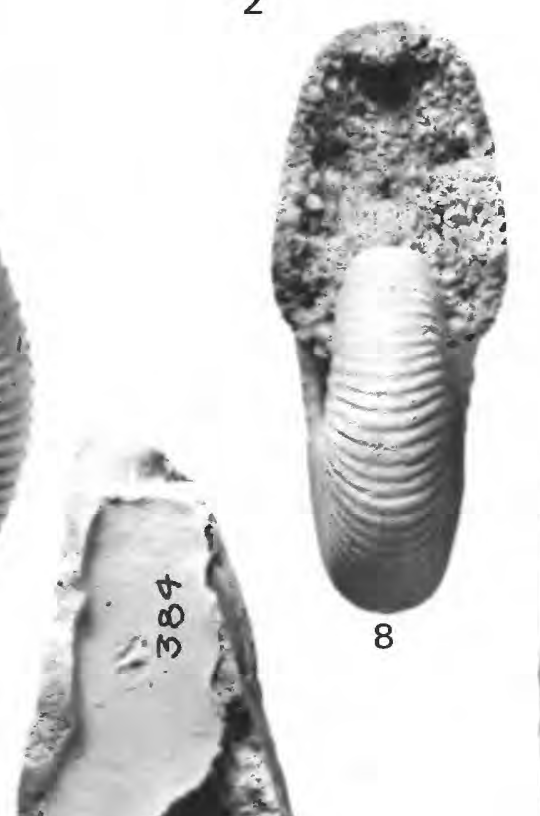


\section{PLATE 2}

[All figures natural size. Arrow points to base of body chamber]

Figures 1-13. Rhaeboceras halli (Meek and Hayden) (p. 6).

1-3. Rear, side, and front views of hypotype USNM 413015, from USGS Mesozoic locality D783 (text fig. 1, loc. 24).

4-6. Front, side, and rear views of hypotype USNM 413016, from the same locality.

7-9. Rear, side, and front views of hypotype USNM 413017, from the same locality.

10-12. Front, side, and rear views of hypotype USNM 413018, from the same locality.

13. Side view of hypotype USNM 413019, from USGS Mesozoic locality D10223 (text fig. 1, loc. 10). See plate 5, figure 3 for rear view. 
U.S. GEOLOGICAL SURVEY

PROFESSIONAL PAPER 1477 PLATE 2

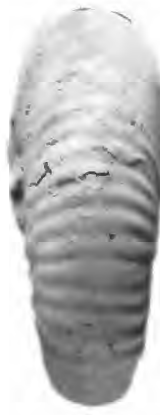

1

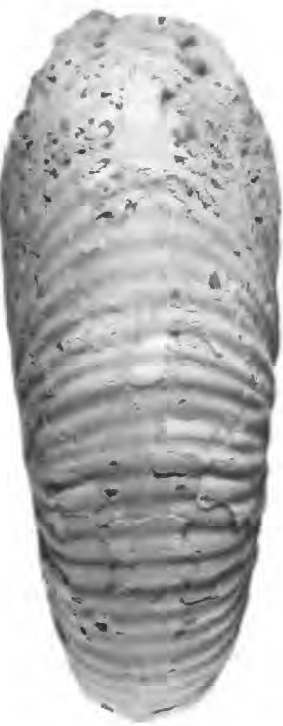

7
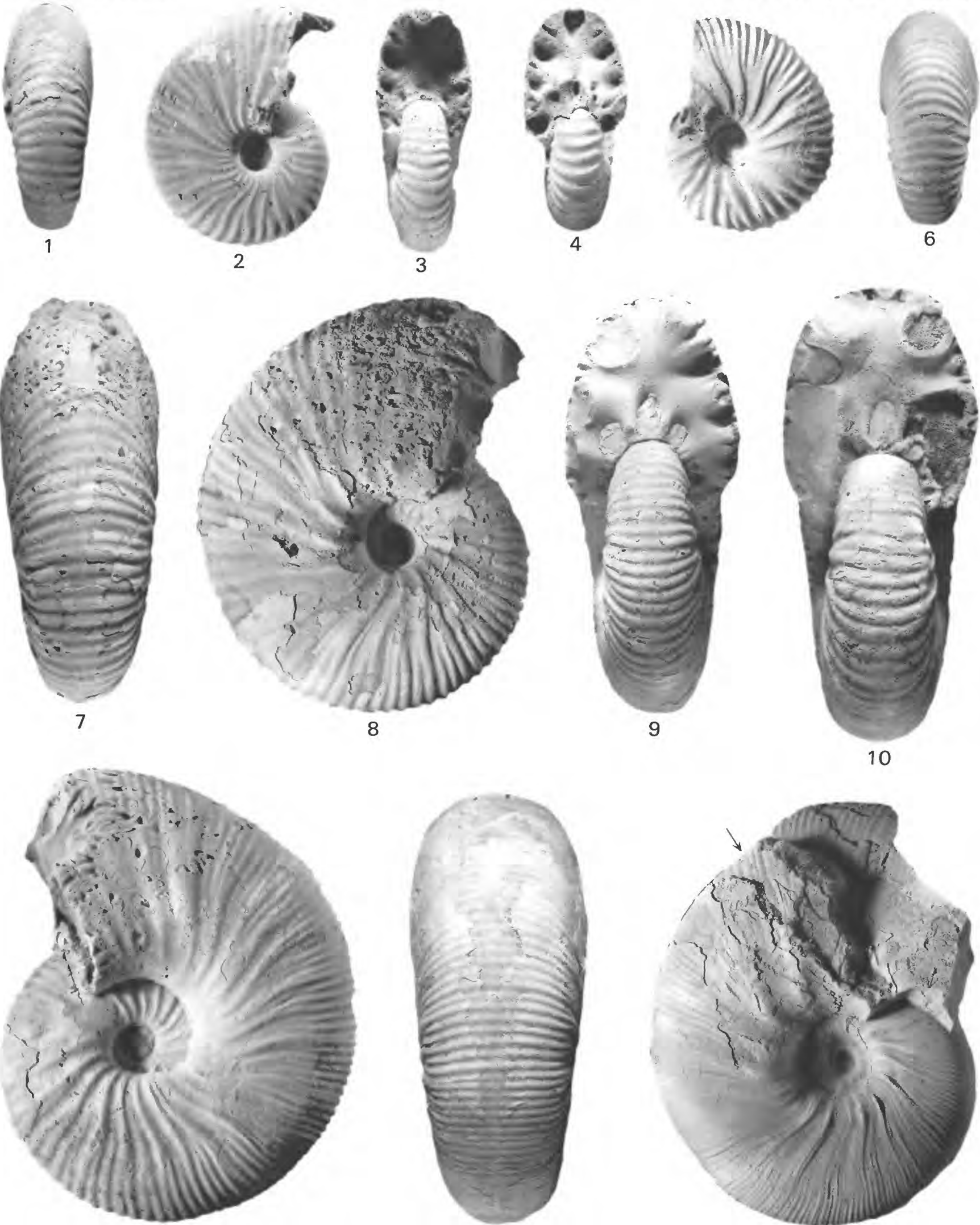

11

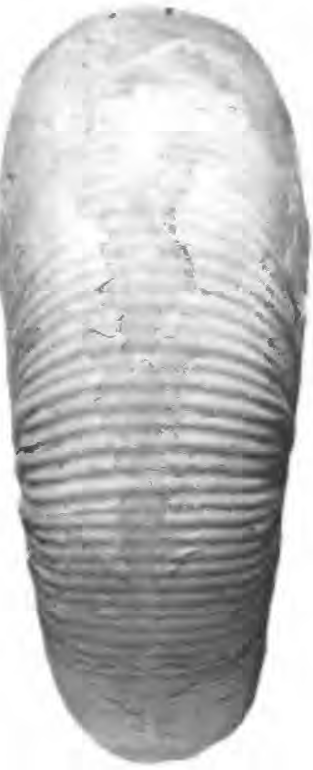

12

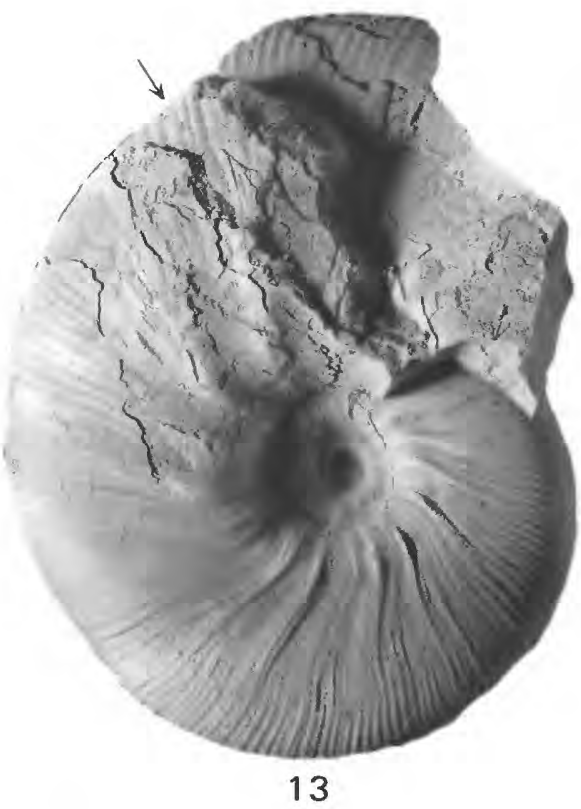

RHAEBOCERAS 
PLATE 3

[All figures natural size. Arrow points to base of body chamber]

Figures 1-8. Rhaeboceras halli (Meek and Hayden) (p. 6).

1, 2. Front and side views of hypotype USNM 413020, from USGS Mesozoic locality D783 (text fig. 1, loc. 24). See plate 11, figure 6 for rear view.

3, 4. Rear and side views of hypotype USNM 413021, from the same locality.

5-7. Front, rear, and side views of hypotype USNM 413022, from the same locality.

8. Side view of a complete adult from the Bearpaw Shale of east-central Montana. Larry C. Eichhorn collection. 
U.S. GEOLOGICAL SURVEY

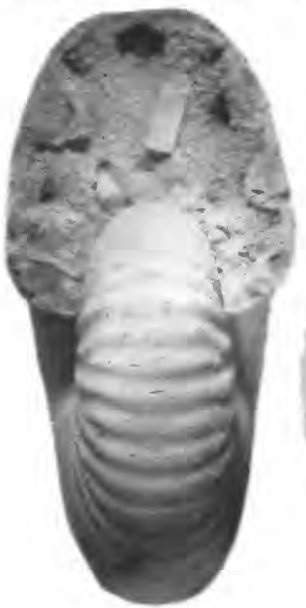

1

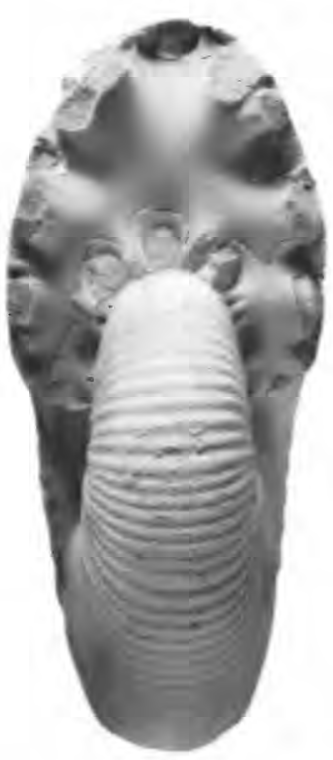

5
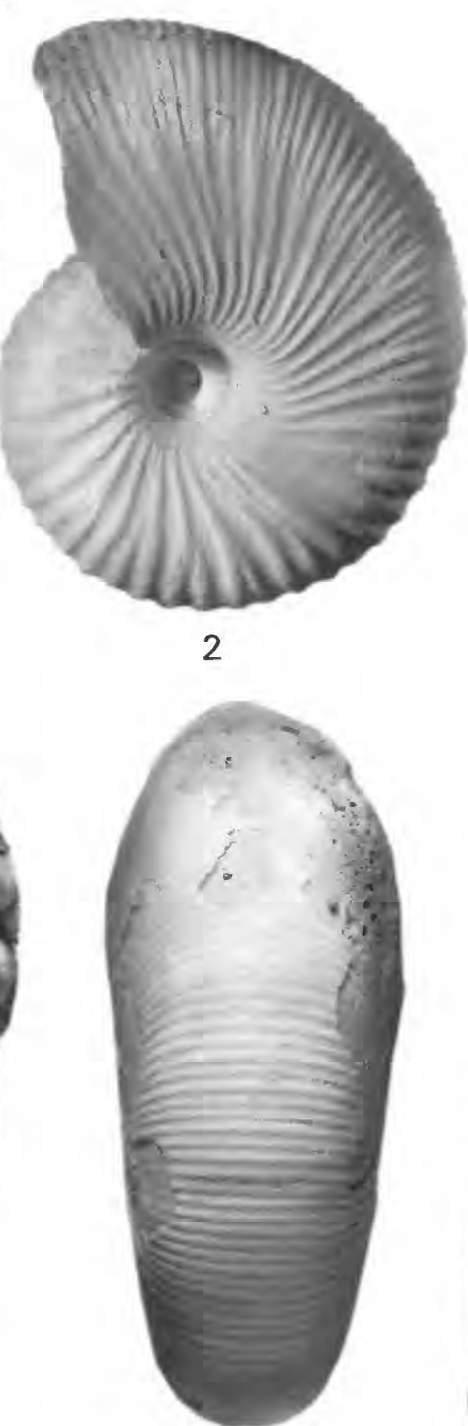

6
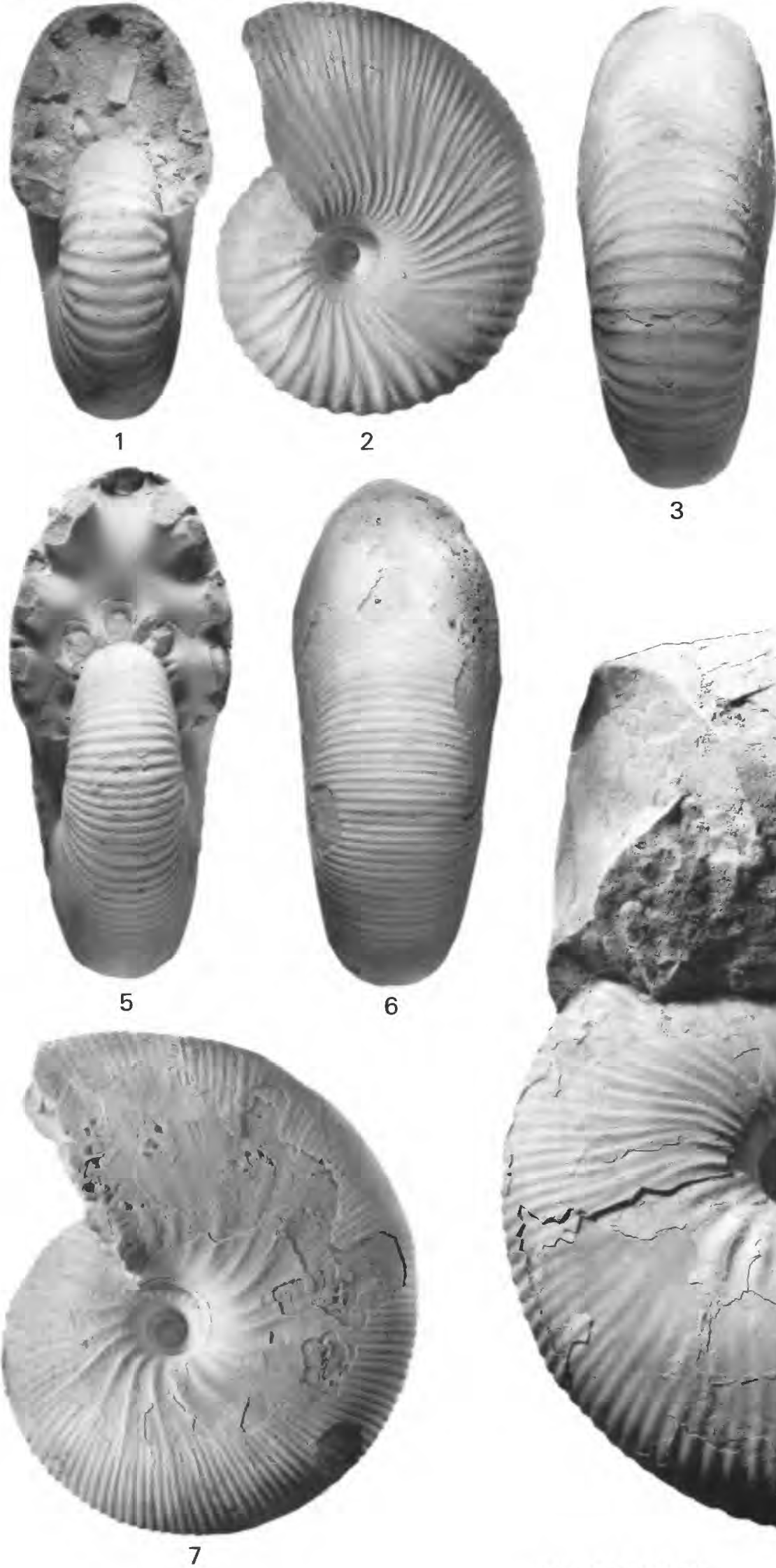

PROFESSIONAL PAPER 1477 PLATE 3
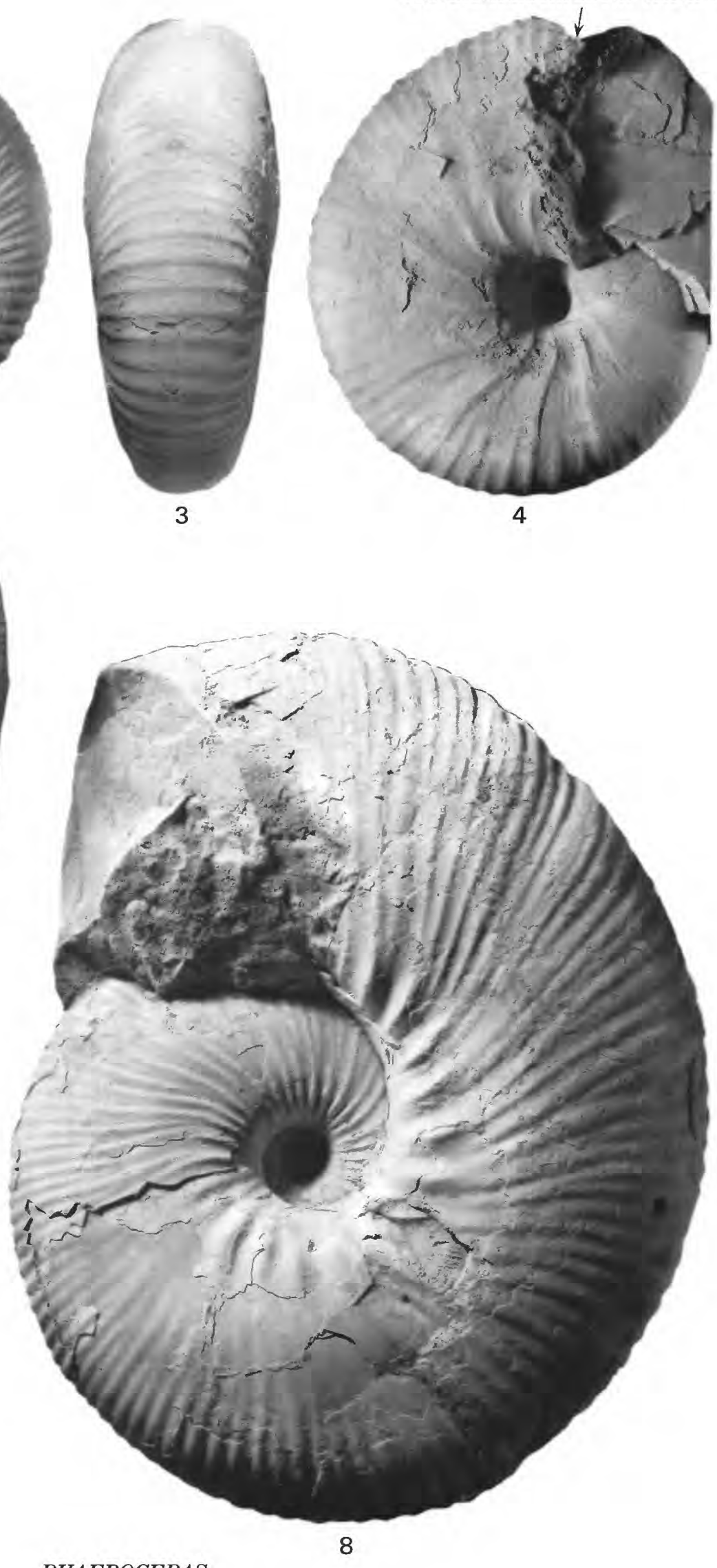

RHAEBOCERAS 
PLATE 4

[All figures natural size. Arrows point to base of body chambers]

Figures 1-5. Rhaeboceras halli (Meek and Hayden) (p. 6).

1-3. Rear, side, and front views of hypotype USNM 413023, from USGS Mesozoic locality D10223 (text fig. 1, loc. 10).

4, 5. Rear and side views of hypotype USNM 413024, from the same locality. 


$$
\begin{aligned}
& 010 \\
& 10
\end{aligned}
$$




\section{PLATE 5}

[All figures natural size. Arrows point to base of body chambers]

FIGURES 1-8. Rhaeboceras halli (Meek and Hayden) (p. 6).

1, 2. Rear and side views of hypotype USNM 413025, a noded variant, from USGS Mesozoic locality D783 (text fig. 1, loc. 24).

3. Rear view of hypotype USNM 413019, from USGS Mesozoic locality D10223 (text fig. 1, loc. 10). See plate 2, figure 13 for side view.

4, 7. Rear and side views of hypotype USNM 413026, from the same locality as figures 1 and 2 .

5,6 . Rear and side views of hypotype USNM 413027, from the same locality. See plate 11, figure 5 for front view.

8. Side view of hypotype USNM 413028, from the same locality. 

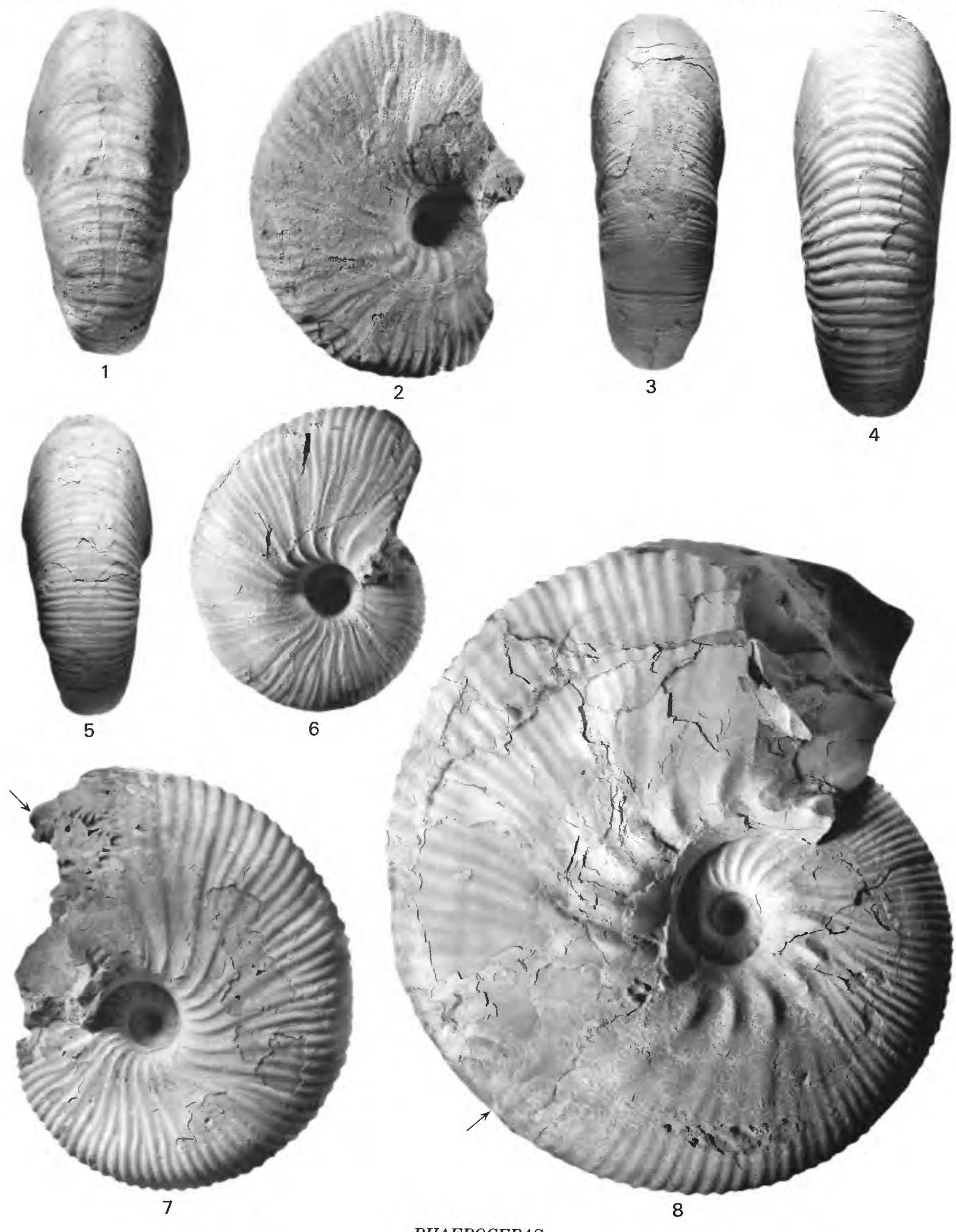

RHAEBOCERAS 


\section{PLATE 6}

[All figures natural size. Arrows point to base of body chambers]

Figures 1-15. Rhaeboceras halli (Meek and Hayden) (p. 6).

From USGS Mesozoic locality 16093 (text fig. 1, loc. 39).

1-3. Rear, side, and front views of hypotype USNM 413029

4-6. Front, side, and rear views of hypotype USNM 413030.

7-9. Rear, side, and front views of hypotype USNM 413031.

10-12. Front, side, and rear views of hypotype USNM 413032.

13-15. Side, front, and rear views of hypotype USNM 413033.

16-21. Rhaeboceras coloradoense Cobban, n. sp. (p. 11).

From the same locality as figures 1-15.

16-18. Rear, side, and front views of paratype USNM 413045.

19-21. Front, side, and rear views of the holotype USNM 413044. 
U.S. GEOLOGICAL SURVEY
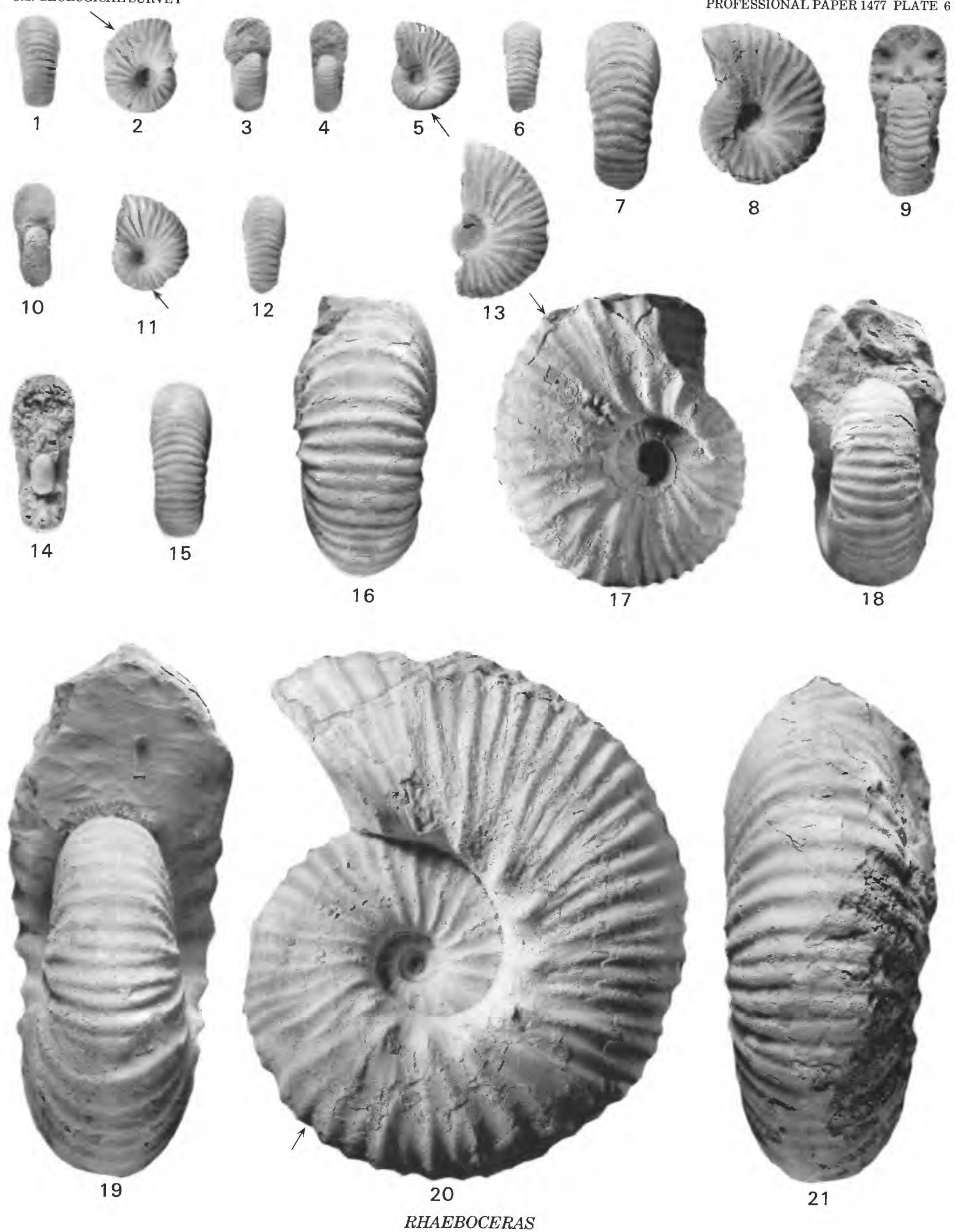


\section{PLATE 7}

[All figures natural size. Arrow points to base of body chamber]

FIGURES 1, 3. Rhaeboceras subglobosum (Whiteaves) (p. 10).

Rear and side views of hypotype USNM 413039, from USGS Mesozoic locality 21660 (text fig. 1, loc. 26).

2. Rhaeboceras halli (Meek and Hayden) (p. 6).

Side view of hypotype USNM 413034, from USGS Mesozoic locality D783 (text fig. 1, loc. 24). See plate 8, figures 1 and 2 for front and rear views.

4-6. Rhaeboceras coloradoense Cobban, n. sp., noded variant (p. 12).

Side, rear, and top views of paratype USNM 413046, from USGS Mesozoic locality 22921 (text fig. 1, loc. 40).

7, 8. Rhaeboceras mullananum (Meek and Hayden) (p. 9).

Front and side views of a plaster cast of the holotype USNM 1924. 


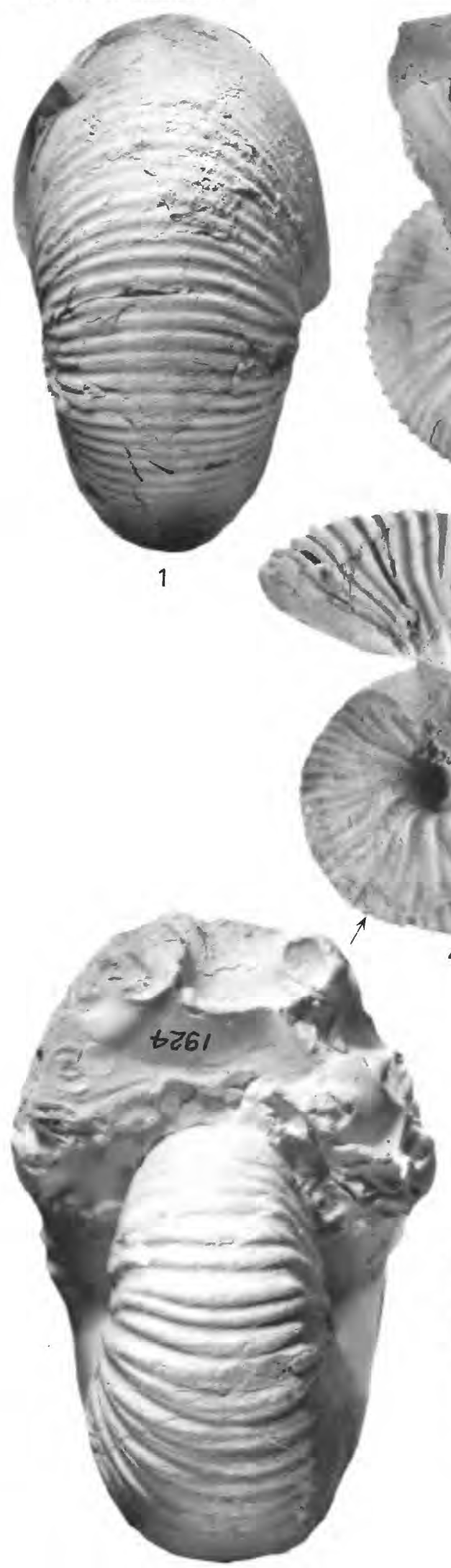

6
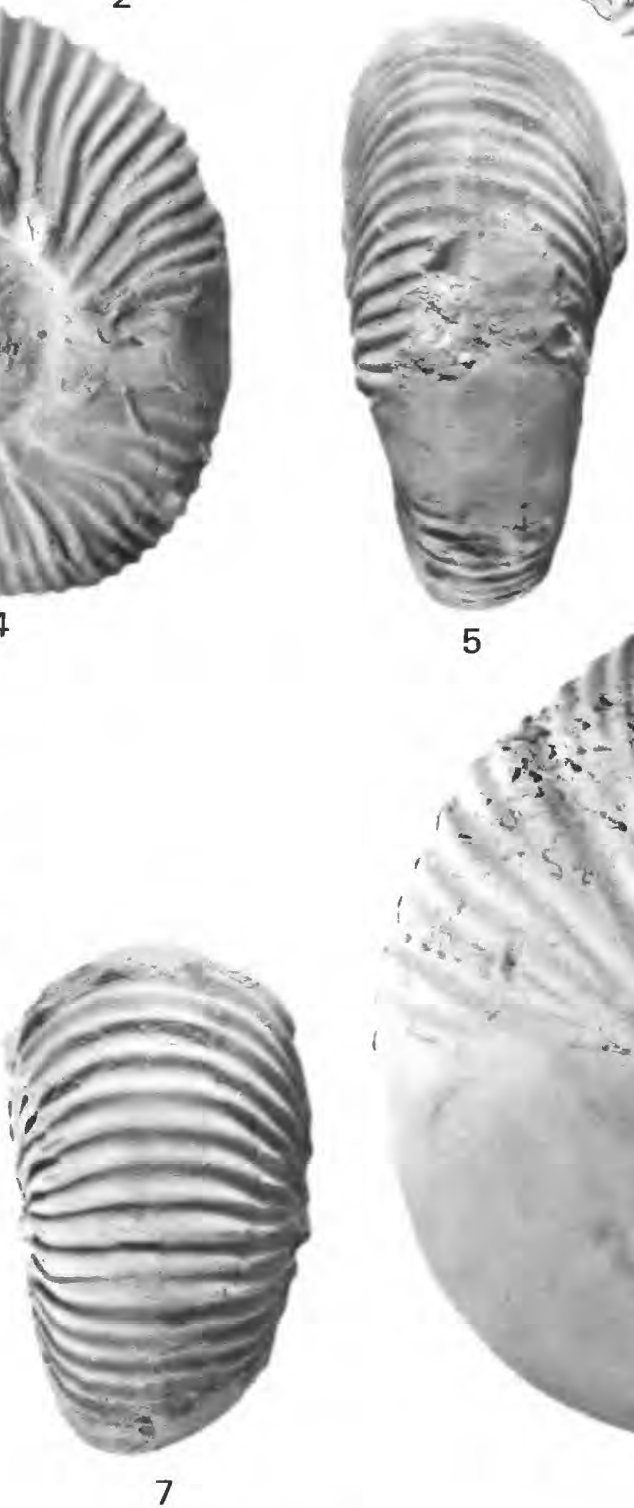

5

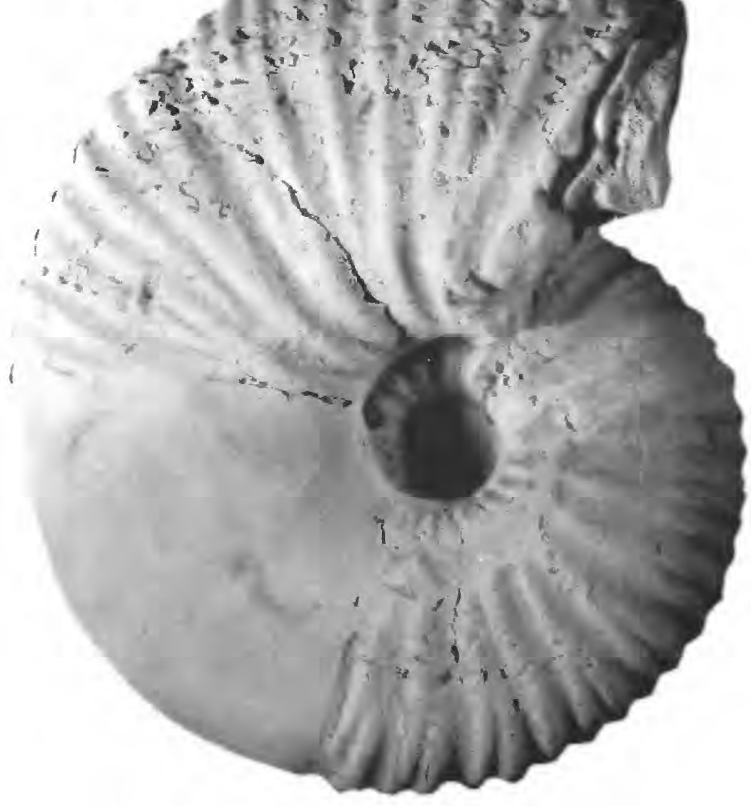

8

RHAEBOCERAS 


\section{PLATE 8}

[All figures natural size]

FIGURES 1, 2. Rhaeboceras halli (Meek and Hayden) (p. 6).

Front and rear views of hypotype USNM 413034, from USGS Mesozoic locality D783 (text fig. 1, loc. 24). See plate 7 , figure 2 for side view.

3-5. Rhaeboceras subglobosum (Whiteaves) (p. 10).

Side, front, and rear views of hypotype USNM 413040, from USGS Mesozoic locality 5517 (text fig. 1, loc. 1). 


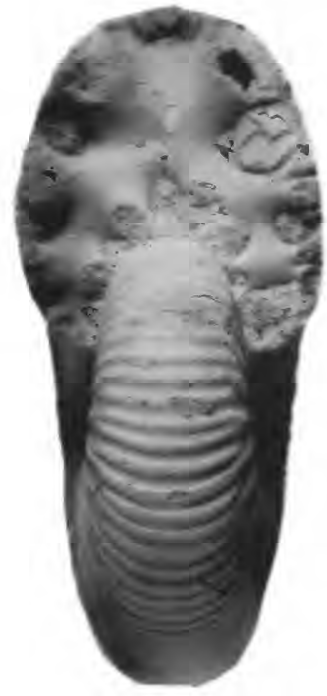

1
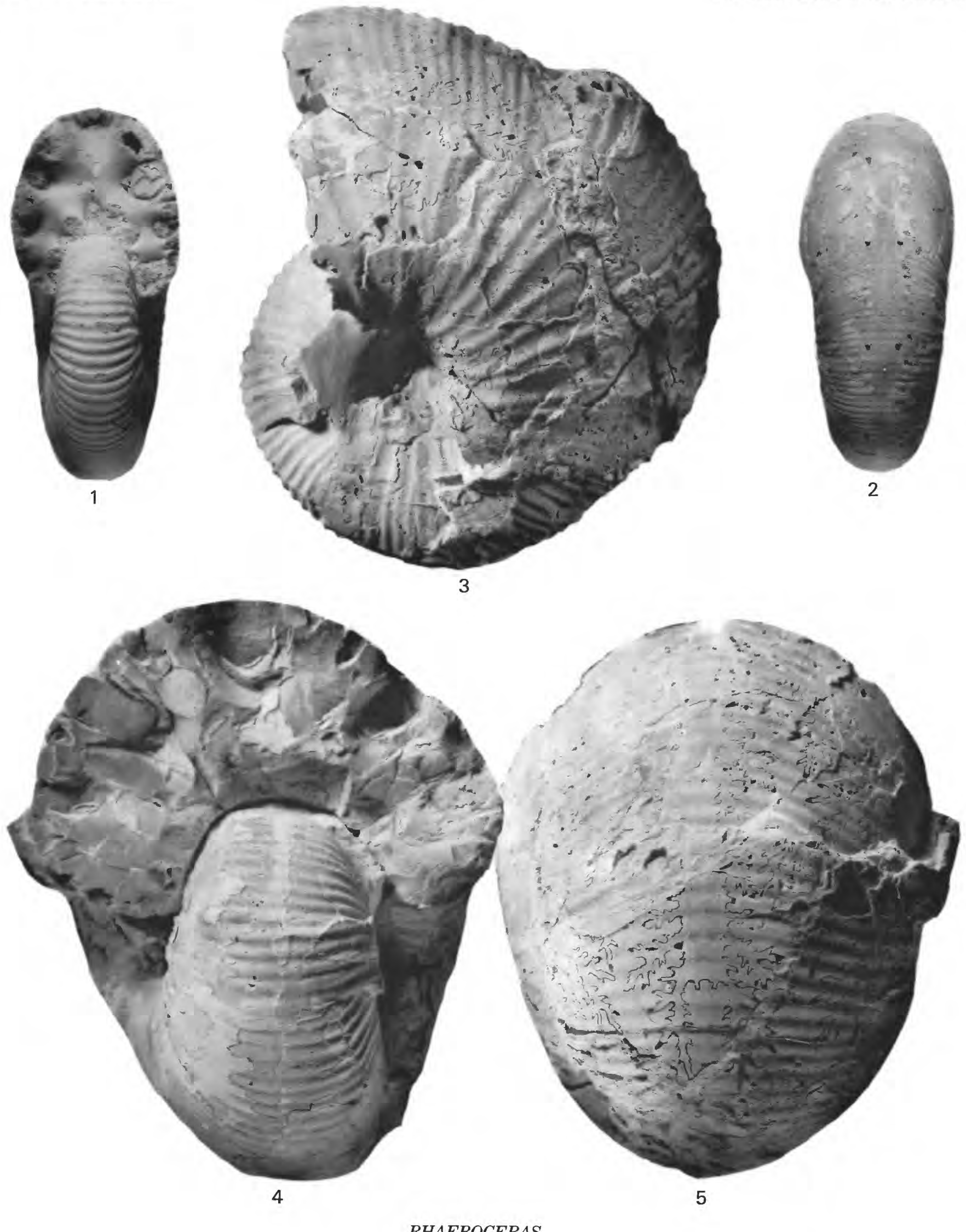

RHAEBOCERAS 


\section{PLATE 9}

[All figures natural size]

FIGURES 1-3. Rhaeboceras albertense (Warren) (p. 9).

Rear, side, and front views of a plaster cast of the lectotype UA 349.

4-6. Rhaeboceras subglobosum (Whiteaves) (p. 10).

Front, rear, and side views of a plaster cast of the holotype of $R$. whiteavesi Landes, GSC 9367. 
U.S. GEOLOGICAL SURVEY
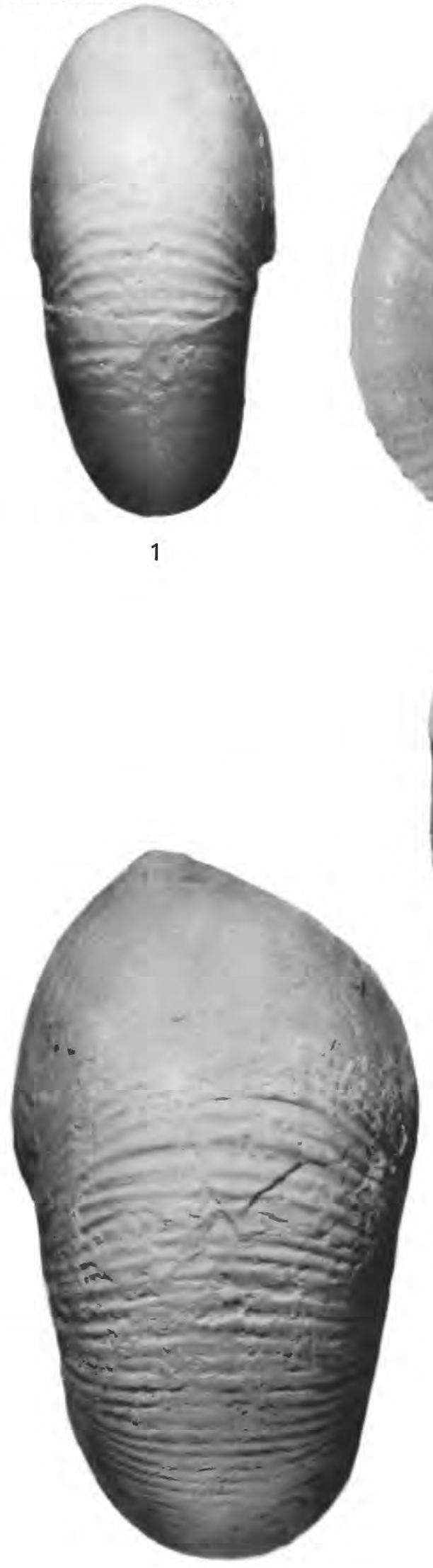

5
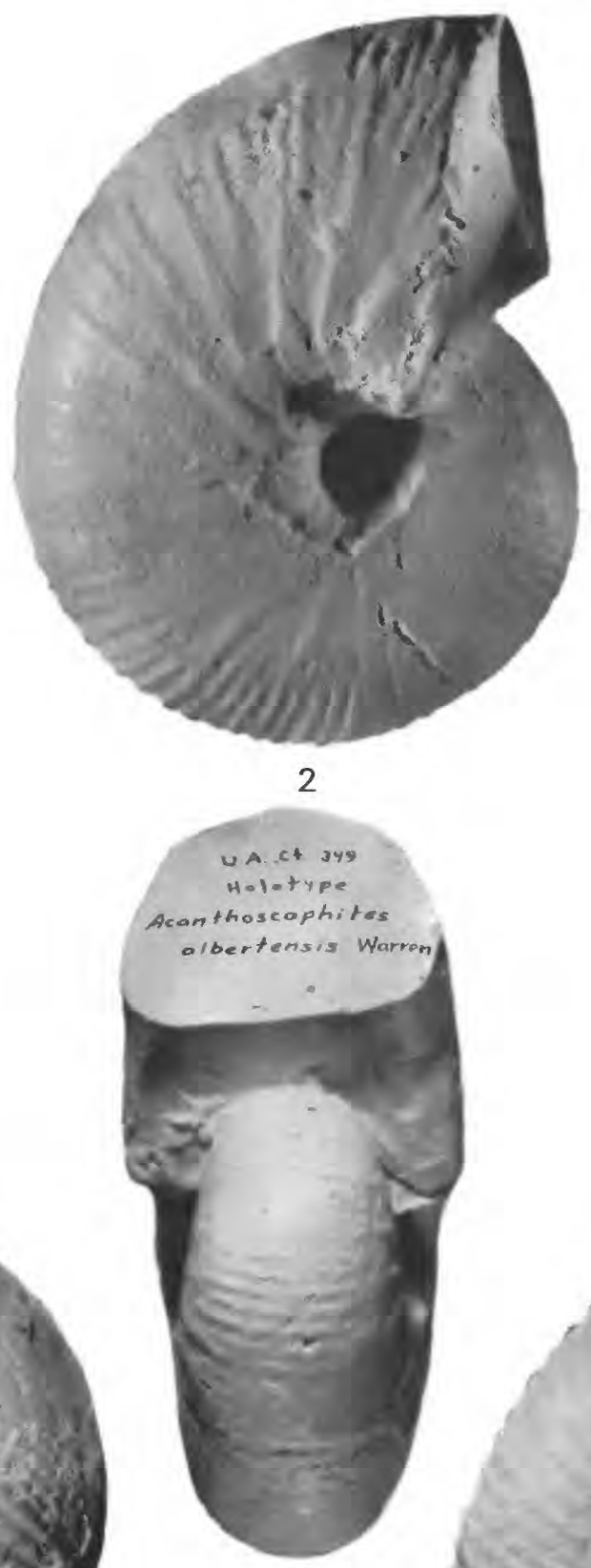

3

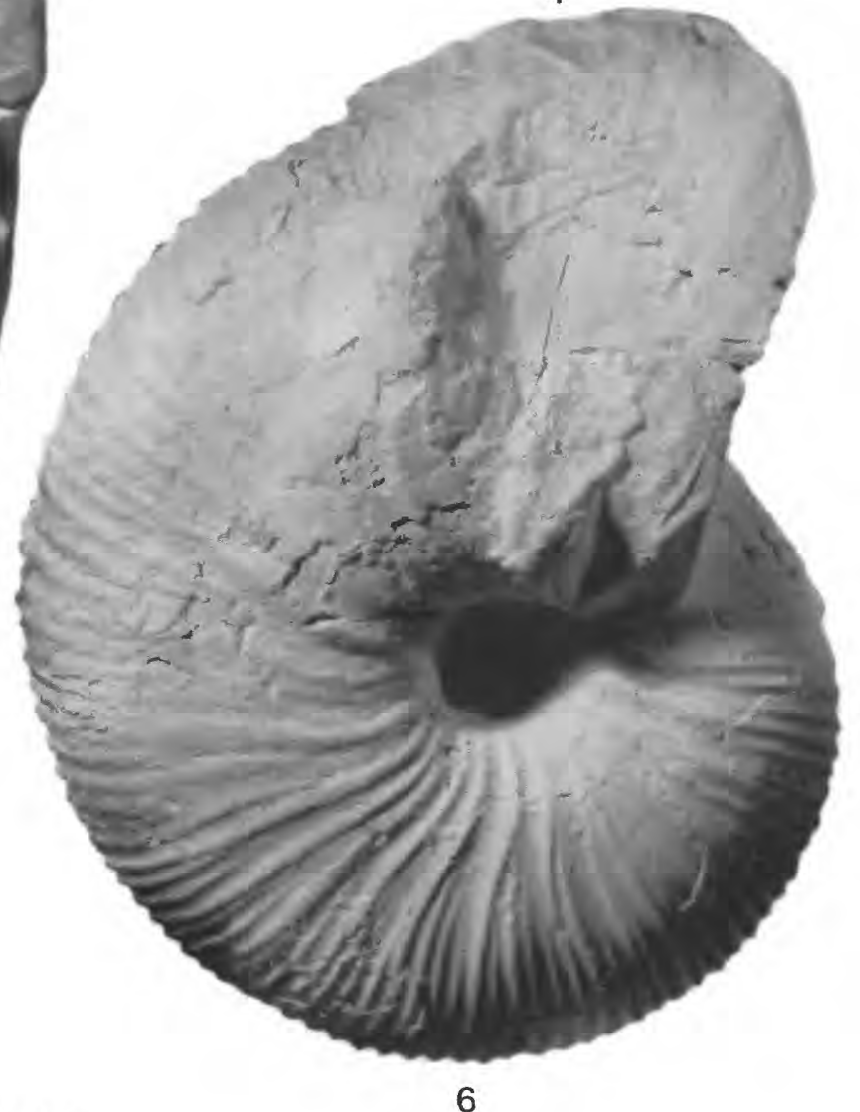

6

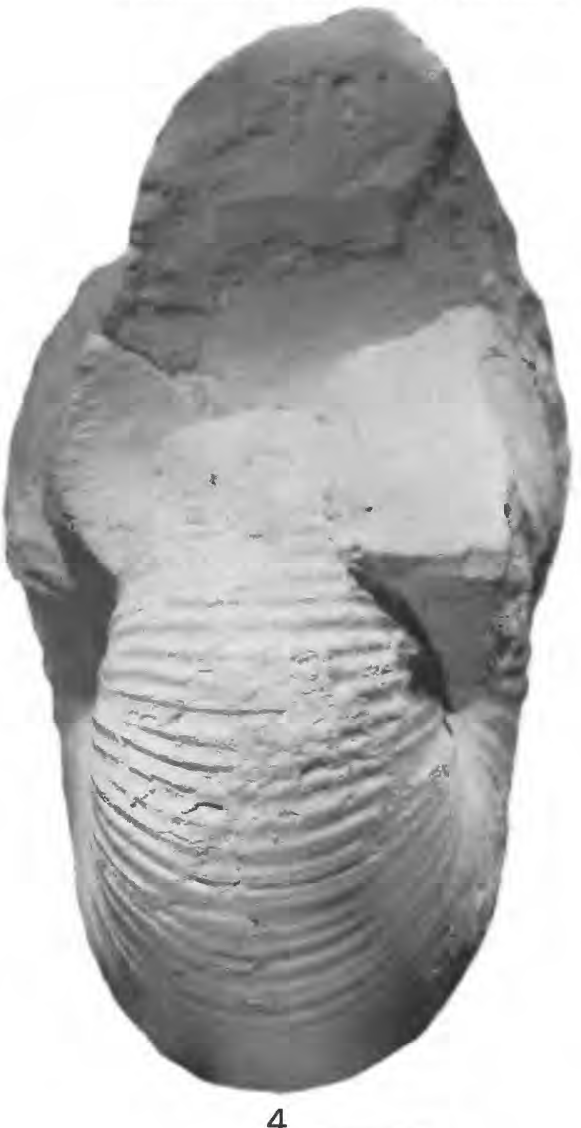

4

$$
\text { , }
$$




\section{PLATE 10}

[Figure about nine-tenths natural size, Arrow points to base of body chamber]

Rhaeboceras subglobosum (Whiteaves) (p. 10).

Side view of hypotype USNM 413041, from USGS Mesozoic locality D1338 (text fig. 1, loc. 2). 


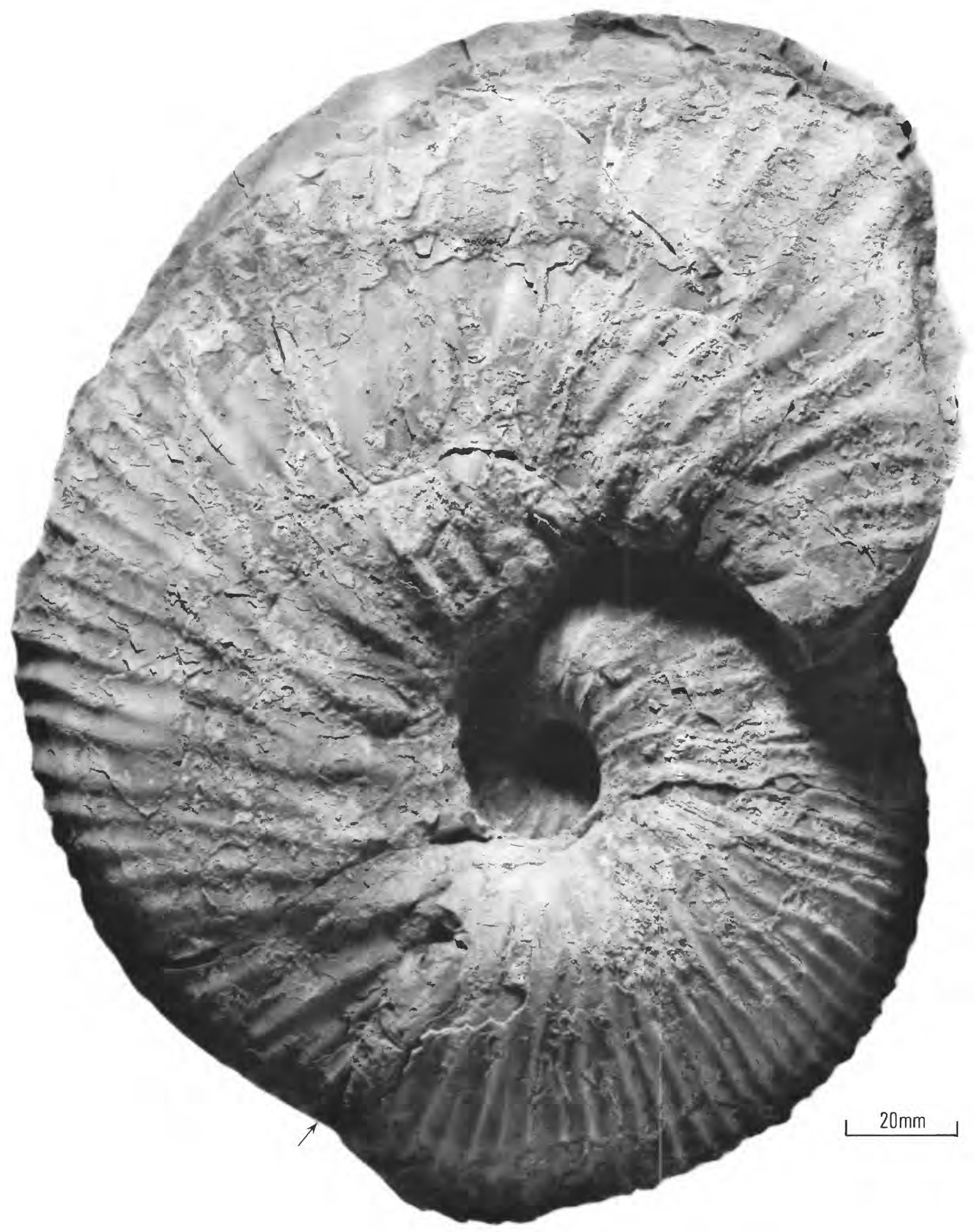




\section{PLATE 11}

[All figures natural size. Arrows point to base of body chambers]

FIGURES 1-4. Rhaeboceras burkholderi Cobban, n. sp. (p. 12).

Front, side, top, and rear views of the holotype USNM 413047, from USGS Mesozoic locality D5663 (text fig. 1, loc. 20).

5, 6. Rhaeboceras halli (Meek and Hayden) (p. 6).

From USGS Mesozoic locality D783 (text fig. 1, loc. 24).

5. Front view of hypotype USNM 413027. See plate 5, figures 5, 6 for rear and side views.

6. Rear view of hypotype USNM 413020 . See plate 3, figures 1,2 for front and side views.

7, 8. Rhaeboceras cf. $R$. burkholderi Cobban, n. sp. (p. 13).

Side and rear views of figured specimen USNM 413048, from the same locality as figures 1-4. 
U.S. GEOLOGICAL SURVEY

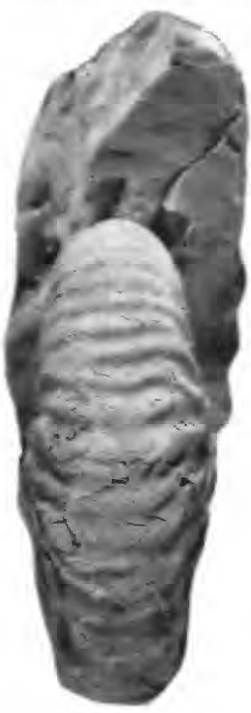

1
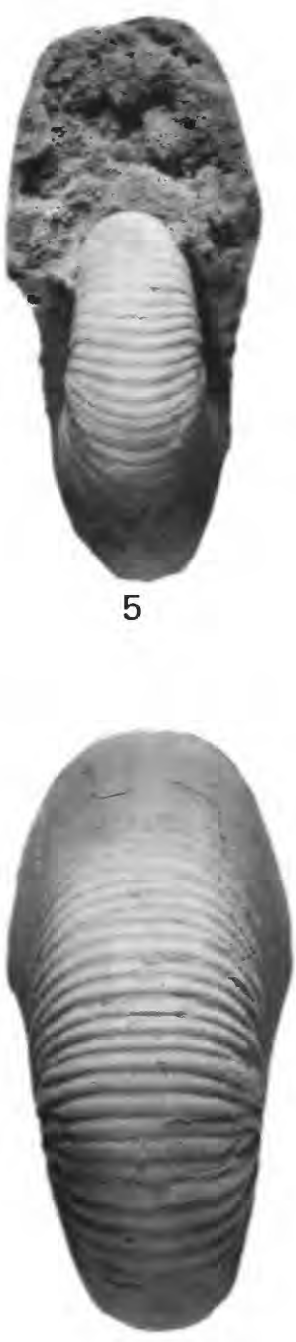

6
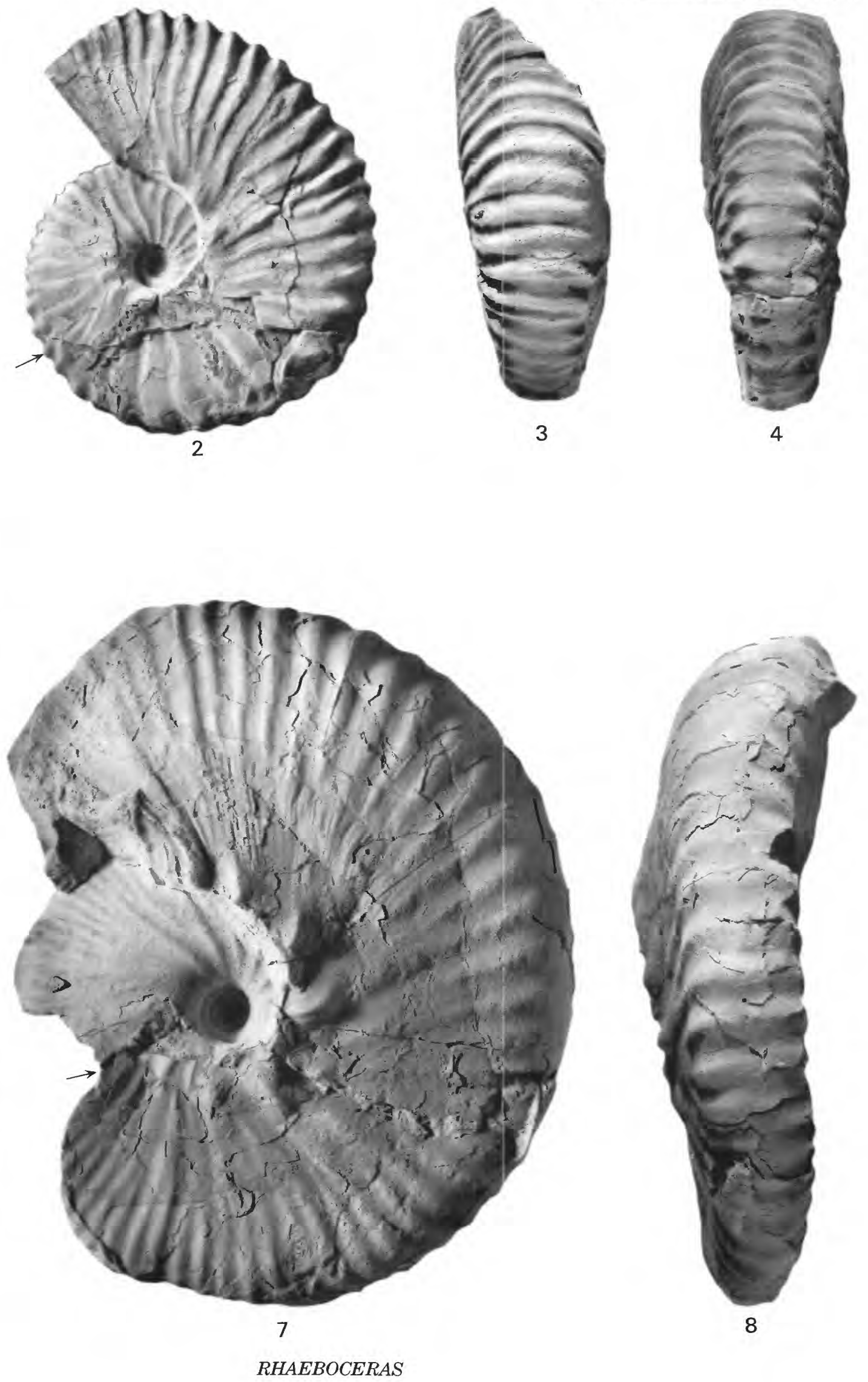


\section{PLATE 12}

[All figures natural size. Arrow points to base of body chamber]

Figures 1-3. Rhaeboceras halli (Meek and Hayden) (p. 6).

Front, side, and rear views of hypotype USNM 413035, from USGS Mesozoic locality 16093 (text fig. 1, loc. 39).

4-7. Rhaeboceras subglobosum (Whiteaves), noded variant (p. 11).

Hypotype USNM 413042, from USGS Mesozoic locality D1382 (text fig. 1, loc. 35).

4, 5. Side and rear views of the inner whorls.

6,7 . Side and rear views of the body chamber and the enclosed inner whorls. 

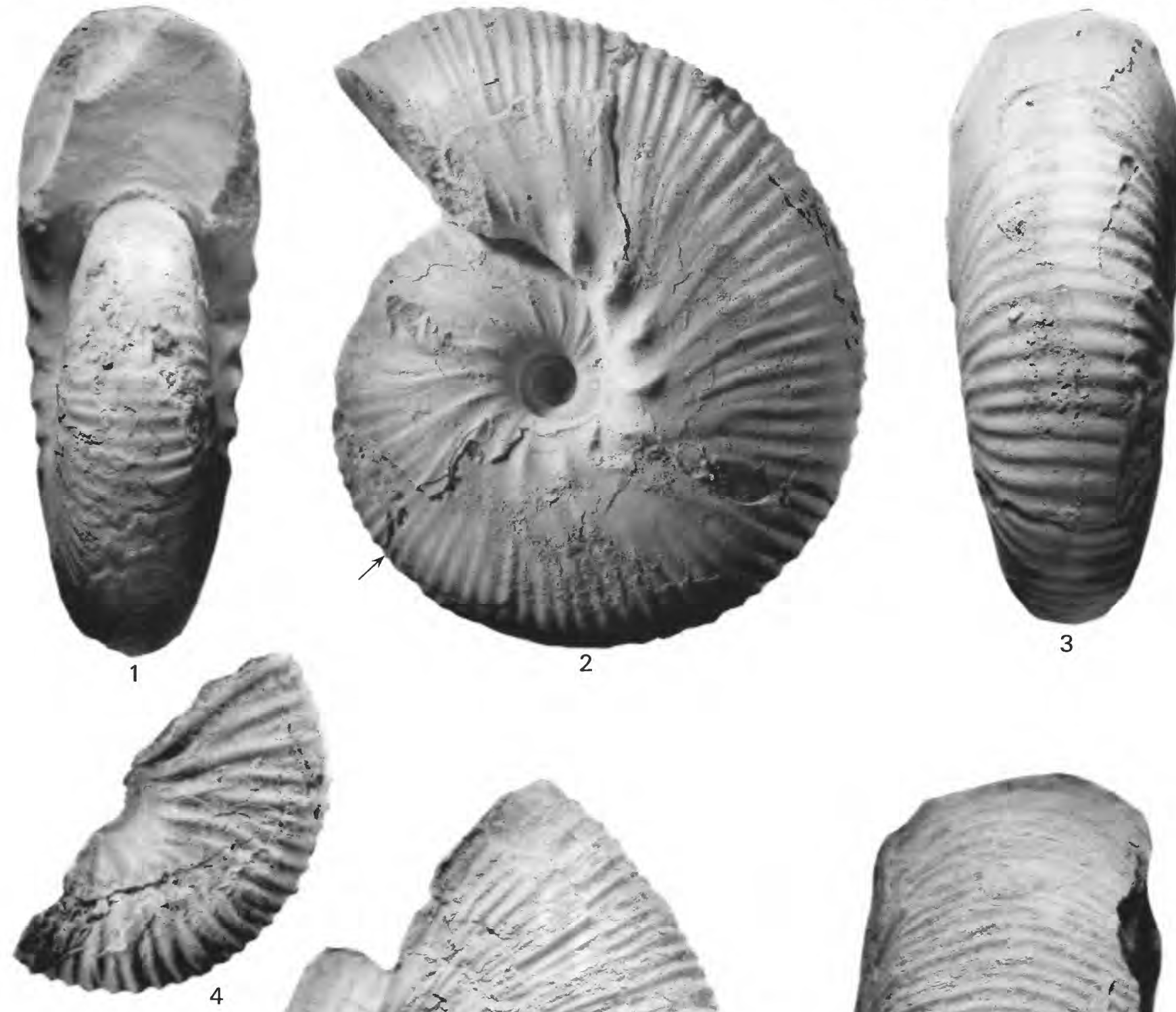

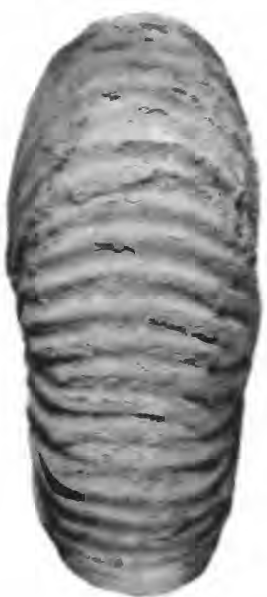

5

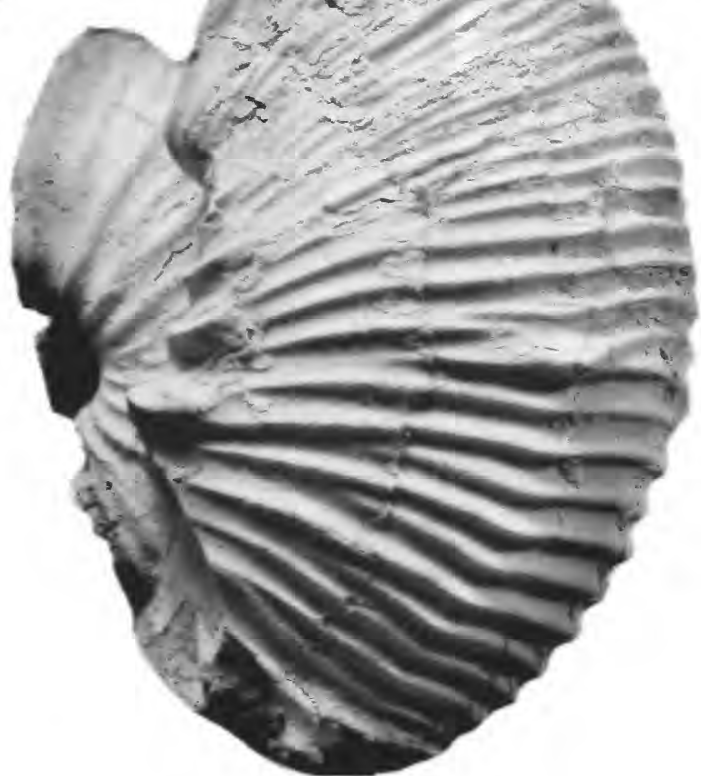

6

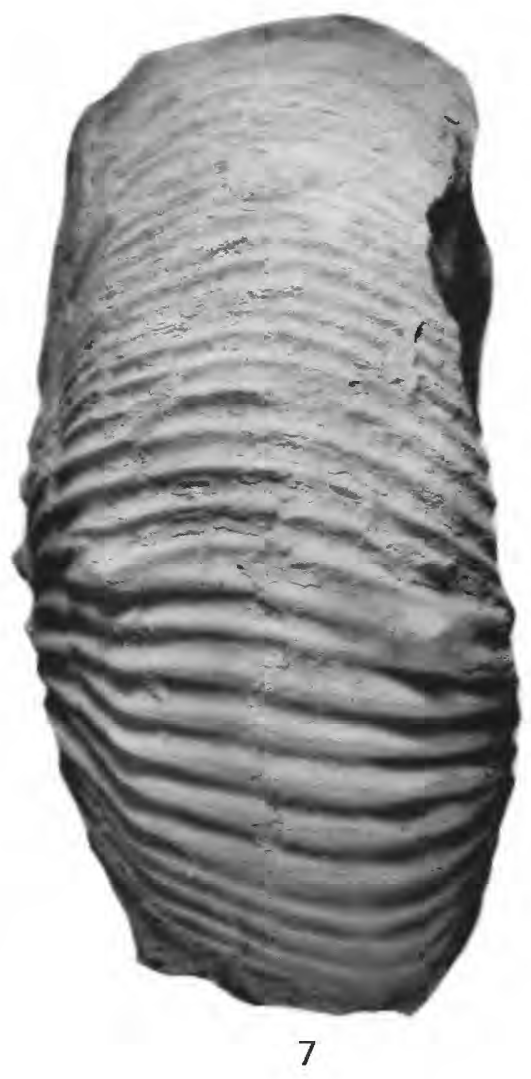

RHAEBOCERAS 


\section{PLATE 13}

[All figures natural size. Arrows point to the base of body chamber]

Figures 1-5. Rhaeboceras halli (Meek and Hayden) (p. 6).

1. Side view of hypotype USNM 413036, from USGS Mesozoic locality D10223 (text fig. 1, loc. 10).

2-5. Rear, front, and side views of a noded variant hypotype USNM 413037, from USGS Mesozoic locality D12734 (text fig. 1, loc. 27). 
U.S. GEOLOGICAL SURVEY
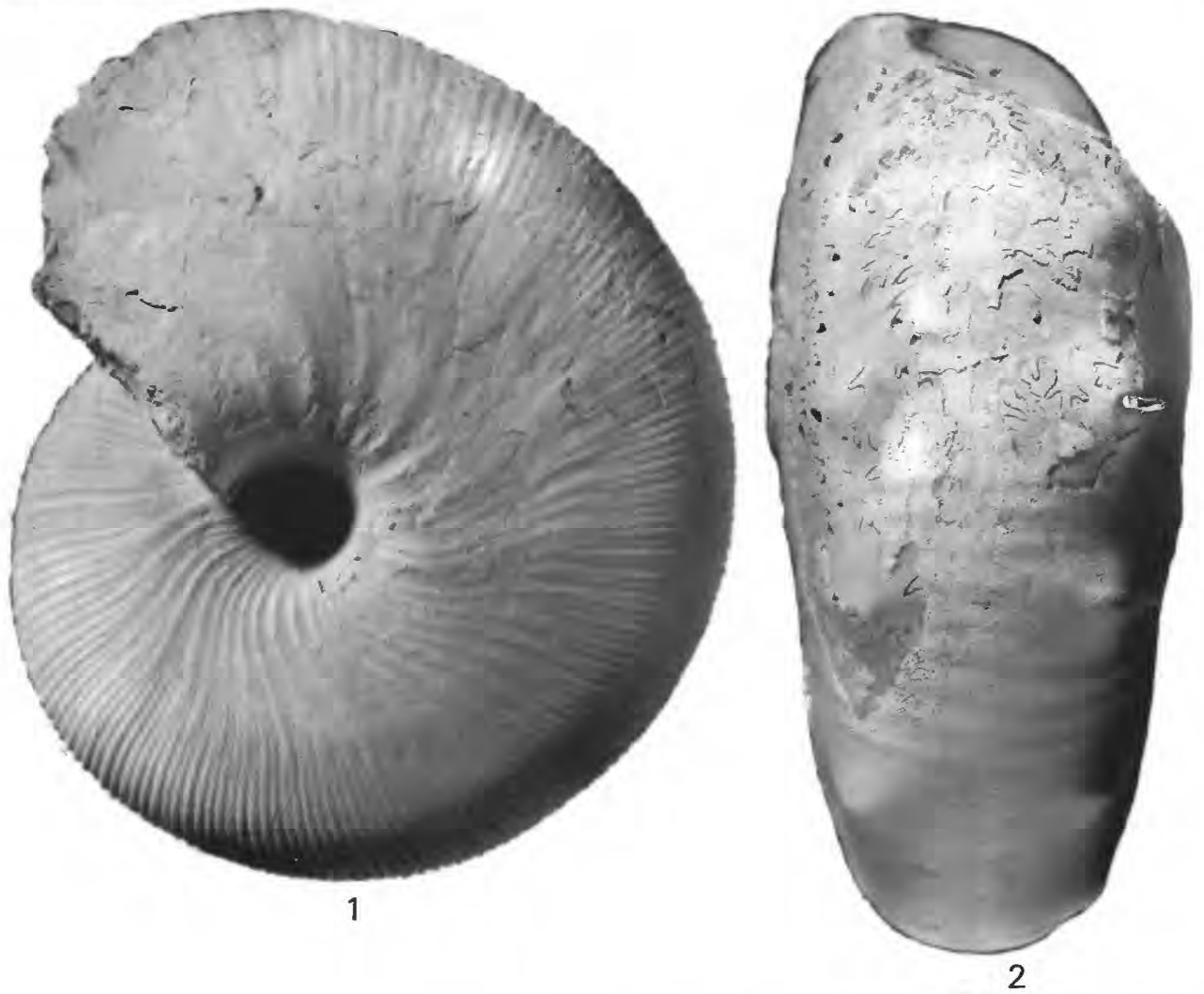

PROFESSIONAL PAPER 1477 PLATE 13

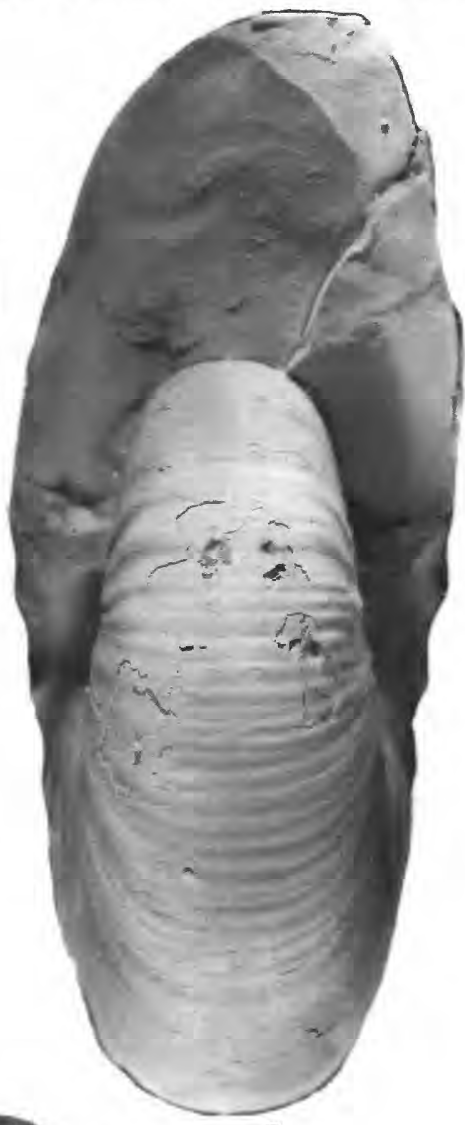

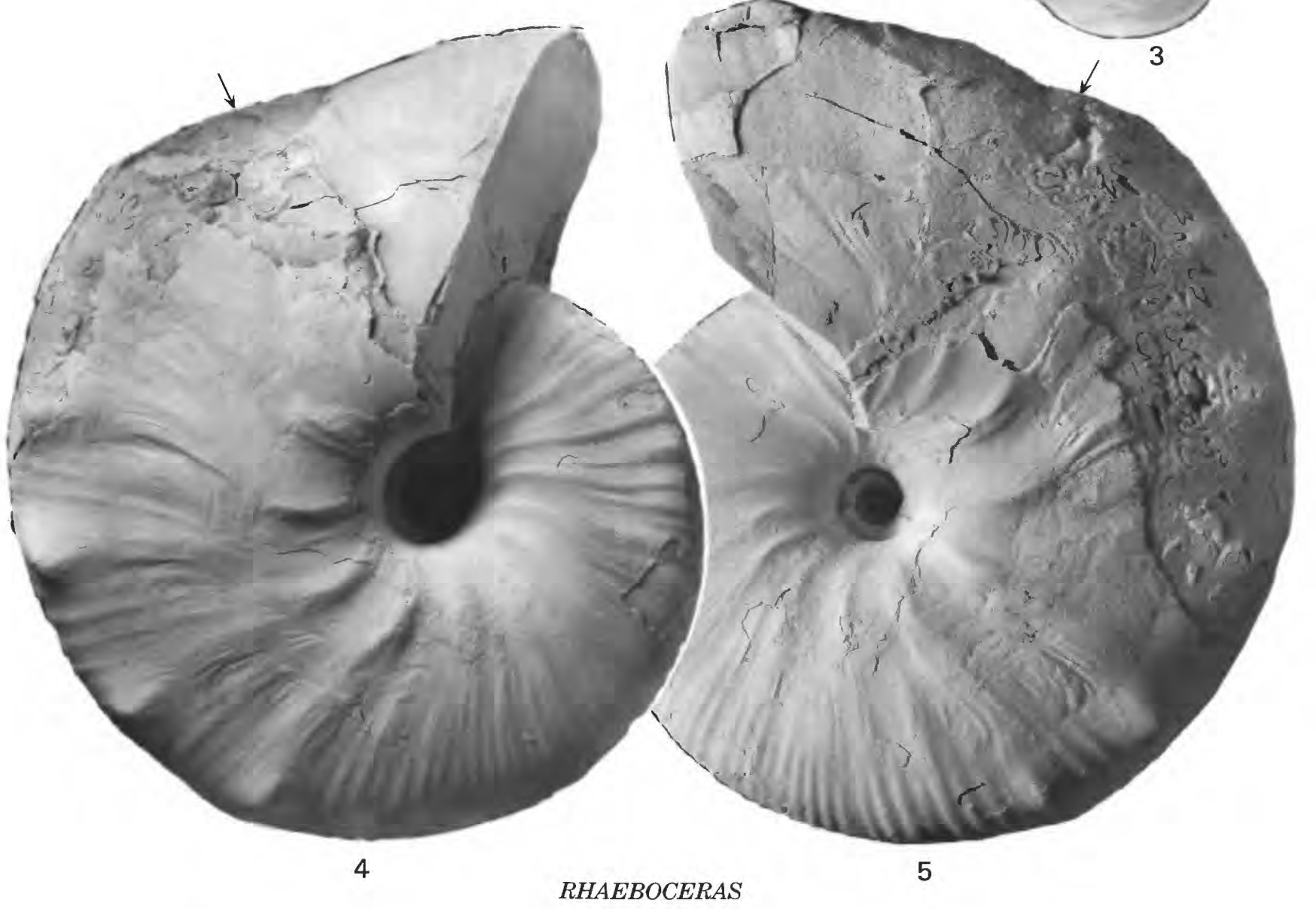




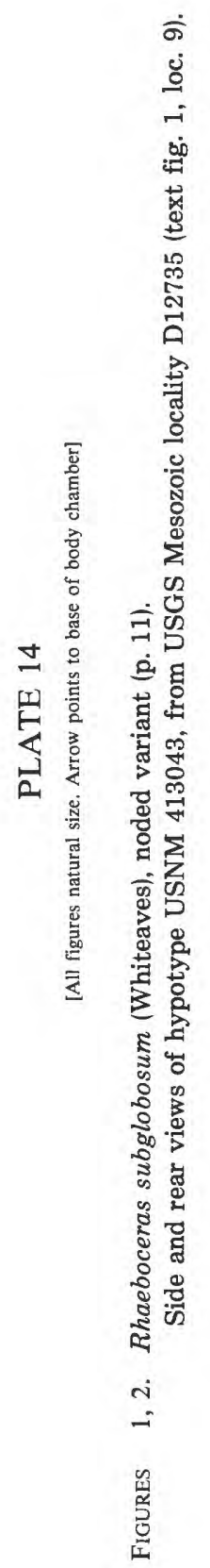



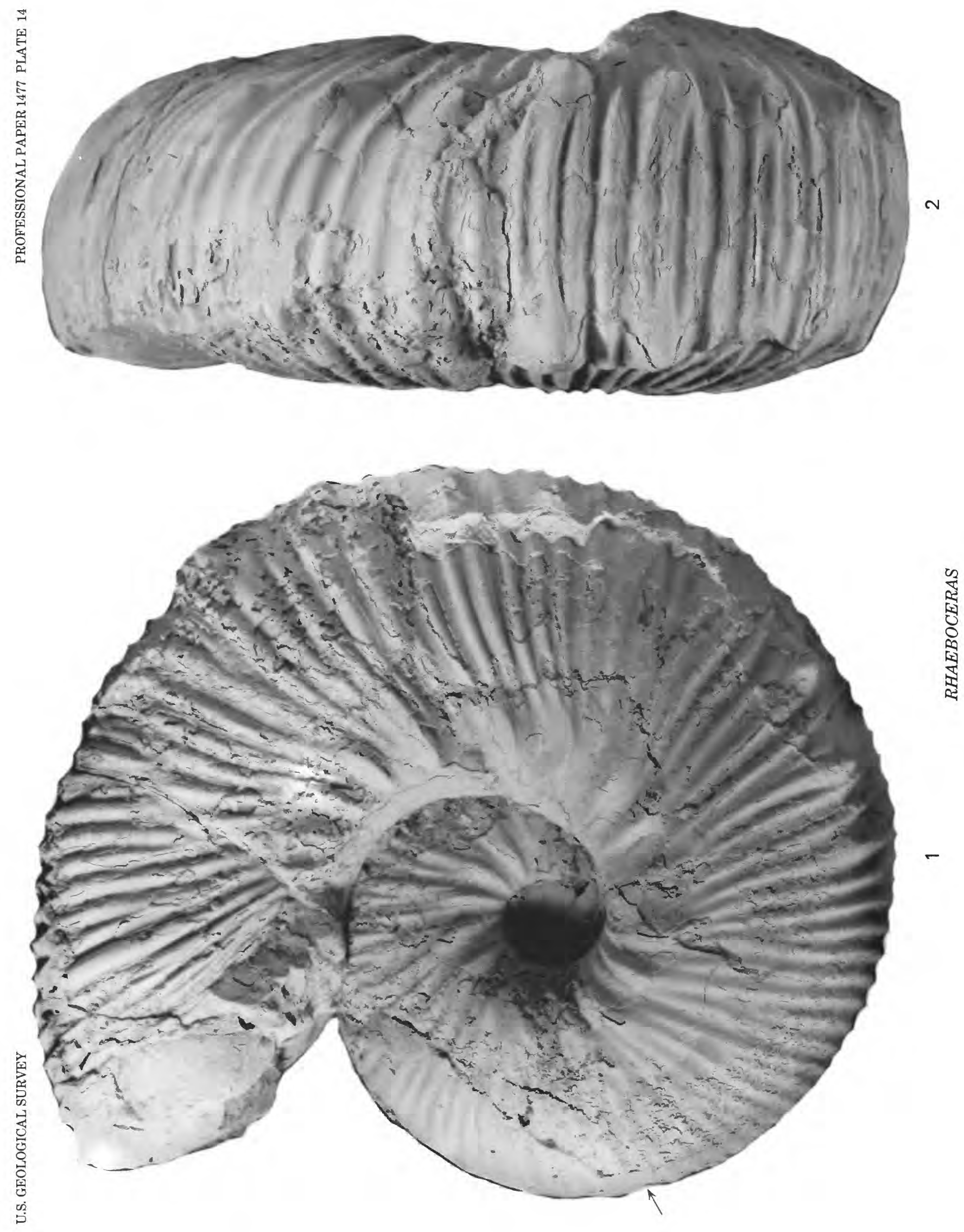